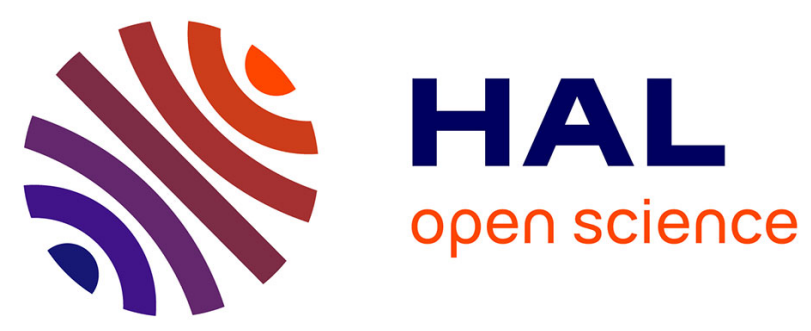

\title{
In-situ estimation of non-regulated pollutant emission factors in an urban area of Nantes, France, with fleet composition characterization
}

Simon Martinet, Yao Liu, Liliane Jean-Soro, Mathieu Goriaux, Michel Andre

\section{- To cite this version:}

Simon Martinet, Yao Liu, Liliane Jean-Soro, Mathieu Goriaux, Michel Andre. In-situ estimation of non-regulated pollutant emission factors in an urban area of Nantes, France, with fleet composition characterization. Transportation Research Part D: Transport and Environment, 2019, 76, pp.193-210. 10.1016/j.trd.2019.09.023 . hal-02350412

\section{HAL Id: hal-02350412 \\ https://hal.science/hal-02350412}

Submitted on 6 Nov 2019

HAL is a multi-disciplinary open access archive for the deposit and dissemination of scientific research documents, whether they are published or not. The documents may come from teaching and research institutions in France or abroad, or from public or private research centers.
L'archive ouverte pluridisciplinaire HAL, est destinée au dépôt et à la diffusion de documents scientifiques de niveau recherche, publiés ou non, émanant des établissements d'enseignement et de recherche français ou étrangers, des laboratoires publics ou privés. 


\section{In-situ Estimation of Non-Regulated Pollutant Emission Factors in an Urban Area of Nantes, France, with Fleet Composition Characterization}

a Univ Lyon, IFSTTAR, AME, LTE, Bron, 69675, France

${ }^{b}$ GERS, LEE, IFSTTAR, Bouguenais, 44344, France

* Corresponding author: yao.liu@ifsttar.fr, Phone: +33 4721424 75, Fax: +33 4723768 37;

Address: 25 avenue François Mitterrand, 69675 Bron, France

\section{Abstract}

The purpose of this study is to estimate the in-situ emission factors of several pollutants (particle number $[\mathrm{PN}]$, black carbon $[\mathrm{BC}]$ and several volatile and semi-volatile organic compounds [VOCs and SVOCs]) in an urban area of Nantes, France, with real-world traffic conditions and characterization of the fleet composition. The fleet composition and driving conditions are characterized by the number of vehicles, their speeds and their types (passenger cars [PCs], light commercial vehicles [LCVs], heavy-duty vehicles [HDVs]) as well as their characteristics (make, model, fuel, engine, EURO emission standard, etc.). The number of vehicles passing on the boulevard is around 20,000 per day with about $44 \%$ of Euro 5 and Euro 6 vehicles. The impacts of fleet composition on emission were analyzed by ANOVA. The results show that the fleet composition has a significant impact on emissions for different pollutants. Higher percentage of gasoline PCs between Euro 4 to Euro 6 and Euro 4 diesel PCs induces more BC emission. Higher percentage of old gasoline and diesel vehicles ( $\leq$ Euro 3 ) induces higher emission of toluene, ethylbenzene and $m+p$ - and o-xylene. Furthermore, emission factors estimated in this work were compared to those calculated in other in-situ studies that show a good agreement. For the chassis bench comparison, the insitu $\mathrm{PN}$ and $\mathrm{BC}$ emission factors are in the same range as those measured for diesel vehicles 
25 without particle filter and gasoline vehicles with direct injection system. These EFs are also

26 comparable with old heavy duty vehicles without particle filter $\left(5 \times 10^{13}-2 \times 10^{14} \mathrm{\#} / \mathrm{km}\right)$.

\section{Keywords}

28 In-situ emission factors; Unregulated pollutants; Fleet composition

30 


\section{Introduction}

On-road vehicle emissions are the main cause of atmospheric pollution in urban areas. Road transport induces particles, black carbon (BC) and of several VOCs and SVOCs (Volatile and Semi-Volatile Organic Compounds) emissions, such as carbonyl compounds (formaldehyde, hexanal), and BTEX (benzene, toluene, ethylbenzene, xylene) as well as various alkanes and alkenes. These VOCs and SVOCs are non-regulated compounds that could serve as secondary particle precursors and have serious negative impacts on human health (Sydbom et al., 2001; Lewtas et al., 2007) and air quality in cities.

The European Union is imposing emission limits for regulated pollutants in order to reduce road-traffic emissions. Facing on these vehicle emission standards, emission factors are derived from dynamometer bench test (Alves et al., 2015; Yang et al., 2015; Louis et al., 2016; Martinet et al., 2017) or from on-board emissions measurements (O'Driscoll et al., 2016; Ntziachristos et al., 2016). These emission factors constituted an input database with different vehicle categories using by emission models (e.g., COPERT, HBEFA, PHEM and MOVES) for air quality studies. However, for these emission models, the emission factors inventories for recent Euro 5 and Euro 6 vehicles are quite poor (Rexeis et al., 2013). Only eighty Euro 5 vehicles and twenty Euro 6 vehicles (with 13 different vehicle models, and only one Euro 6 gasoline car) were added to HBEFA Version 3.2 for regulated compounds, which may not be representative of the entire fleet composition. The emissions of non-regulated pollutants are rarely measured and integrated in emission models. As consequence, their emission factors for an entire fleet could not be estimated correctly actually due to this deficiency of database, and their impact on air quality and human health could not be investigated accurately. 

methods. The first is the chasing method, where pollutant concentrations are measured by driving a mobile measurement platform behind either a single vehicle (Karjalainen et al., 2014; Ježek et al., 2015) or part of the fleet present on the road (Yli-Tuomi et al., 2005; Wang et al., 2009; Westerdahl et al., 2009; Kam et al., 2012; Ning et al., 2012; Hudda et al., 2013). In the second method, traffic pollutant concentrations are collected by a fixed measurement platform placed on the roadside. This method makes it possible to measure emissions for an entire fleet driving near the measurement site (Ketzel et al., 2003; Imhof et al., 2005; Rose et al., 2005; Jones et al., 2006; Bukowiecki et al., 2010). For most of these studies, the number of LDVs, HDVs and buses are counted and the traffic speeds are measured in some cases. However, the fleet compositions with vehicle engine, capacity, combustion, age and Euro emission standard were not fully characterized. As consequence, the impacts of fleet composition on non-regulated pollutant emissions are hardly investigated. Furthermore, the on-road emission factors in these cited studies were mainly calculated for particles and BC. Very few on-road emission factors studies were focused on secondary particle precursors (carbonyl compounds, BTEX and alkanes...). Ning et al. (2012) determined on-road emission factors for butane, but only for an HDV/bus fleet.

In this paper, the emission factors of particle number (PN), BC, and several aliphatic, aromatic and carbonyl compounds were estimated using the different concentrations of $\mathrm{NO}_{\mathrm{x}}$ and a pollutant between a background measurement site and a traffic measurement site with the fleet composition observed during the measurements campaign. Furthermore, the fleet composition was characterized based on the vehicle type, make, model, fuel, engine, age, Euro emission standard, as well as the traffic conditions, traffic speed, and congestion. 
ANOVA statistical analyses were performed to characterize the impact of fleet composition

on emissions. Furthermore, the emission factors estimated in this study were compared to other emission factors calculated in previous in-situ studies and those measured on a dynamometer bench.

\section{Experimental Method}

\subsection{Measurement Sites}

The measurements were conducted at two sites in the city of Nantes, France, between April 19 and 30, 2017. The first site was an urban background (47 $\left.13^{\prime} 20.3^{\prime \prime} \mathrm{N} 1^{\circ} 32^{\prime} 15.2^{\prime \prime} \mathrm{W}\right)$ site to measure urban background pollutant concentrations over a period of four days. The second site was a traffic site in the city center $\left(47^{\circ} 12^{\prime} 16.0^{\prime \prime} \mathrm{N} 1^{\circ} 33^{\prime} 10.9^{\prime \prime} \mathrm{W}\right)$. It is an urban boulevard with two lanes of traffic in each direction, a speed limit of $30 \mathrm{~km} / \mathrm{h}$, and traffic lights (Fig. 1). The number of vehicles passing on the boulevard is around 20,000 per day. Trucks and buses pass on the boulevard but with a low frequency. Measurements were conducted over a period of seven days.

\subsection{Traffic Characterization}

The fleet composition and traffic conditions on the traffic site were characterized by AlyceSofreco (a private company specialized in the field of traffic measurement). These data were recorded in both directions of traffic and over a period of seven days using two video cameras and pneumatic-tube automatic traffic counters. The counters determined the number of vehicles and the driving conditions (speed, traffic congestion, etc.) and the video cameras collected the license plate numbers of each vehicle. Using these license plate 
numbers, AAAData (a private company) provided the characteristics of each vehicle,

100 including its make, model, vehicle type, fuel, engine, date of entry into circulation and Euro

101 emission standard according to the vehicle type (LDV and HDV).

102

\subsection{Sampling Devices}

The sampling devices were installed in a truck that been specially fitted with an array of analyzers to sample the ambient air. The truck was placed along the edge of the road on the traffic site and the sampling was carried out around at a height about two meters and at a distance of $0.5 \mathrm{~m}$ of the road (Fig. 1). A Fast Mobility Particle Sizer (FMPS ${ }^{\mathrm{TM}}$; TSI) was used to measure the distribution and total particle number ranging from 5.6 to $560 \mathrm{~nm}$ with $1 \mathrm{scan} / \mathrm{s}$ at a flow rate of $8 \mathrm{~L} / \mathrm{min}$, with a concentration range from 0 to $10^{7}$ particle $/ \mathrm{cm}^{3}$. An Aethalometer (AE-33-7, Magee Scientific) was used to measure the $\mathrm{BC}$ concentration. The data are collected once a second and at a flow rate of $5 \mathrm{~L} / \mathrm{min}$. The concentration ranges from 10 to $10^{5} \mathrm{ng} / \mathrm{m}^{3}$ with a detection limit of $5 \mathrm{ng} / \mathrm{m}^{3}$ for 1 hour. The device measures the light attenuation for seven wavelengths from UV to IR (370, 470, 525, 590, 660, 880 and 940 $\mathrm{nm})$. The $880 \mathrm{~nm}$ wavelength corresponding to the maximum amount of $\mathrm{BC}$ was used for the quantification in this study.

VOCs and SVOCs were sampled on different cartridges with 1 sample per hour. DNPH and Tenax ${ }^{\circ}$ cartridges were used to collect respectively carbonyl compounds and BTEX and five majority alkanes with a flow rate of $1 \mathrm{~L} / \mathrm{min}$ and $0.1 \mathrm{~L} / \mathrm{min}$. A private laboratory, TERA Environnement, analyzed the cartridges (78 TENAX and $78 \mathrm{DNPH}$, including 28 for the background site, 49 for the traffic site and 1 for the transport blank for each type of cartridge) using standardized analytical methods (ISO-16000-6, ISO 16000-3, NIOSH 2549, 
121 NIOSH 5506 and NF X 43-025). The complete list of compounds (six BTEX, five alkanes and 11 carbonyl compounds) analyzed on the cartridges is given below.

- BTEX: benzene, toluene, ethylbenzene, m-xylene, p-xylene, o-xylene.

- Alkanes: nonane, decane, undecane, cyclopropane, ethyl, cyclohexane, ethyl.

- Carbonyl compounds: formaldehyde, acetaldehyde, acetone, acrolein, propionaldehyde, crotonaldehyde, methacrolein, butanal, benzaldehyde, pentanal, hexanal.
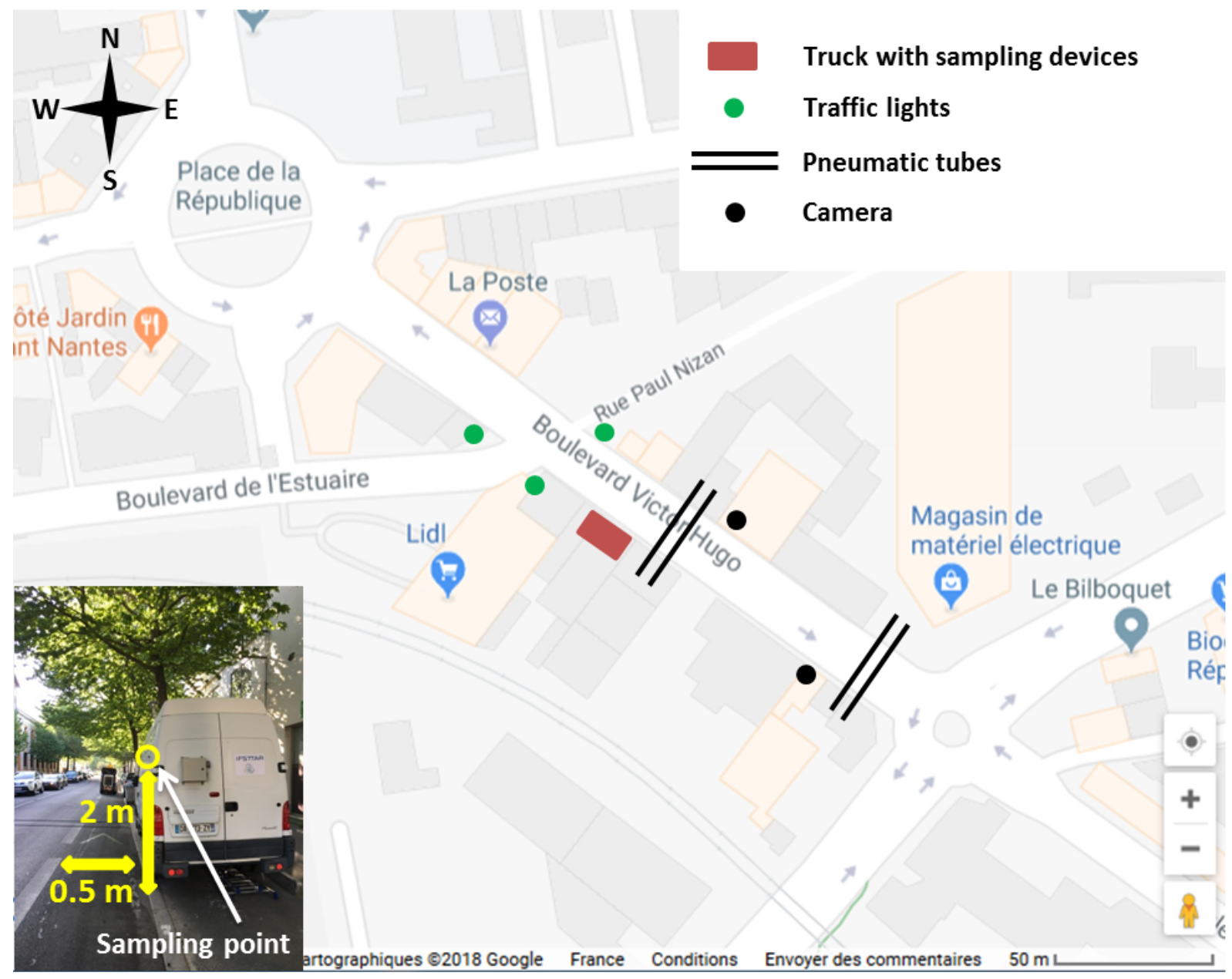

128 Fig. 1. Diagram of the traffic site used for the measurements. 
The variation of $\mathrm{NO}_{\mathrm{x}}$ and pollutant concentrations between the background site and the traffic site were used for estimating road-traffic emission factors (Imhof et al., 2005; Jones et al. 2006; Johansson et al., 2009; Krecl et al., 2017). This method is based on the assumption that the dilution of the pollutant between the exhaust outlets of vehicles and the sampler device inlets and the behavior in the atmosphere are comparable for $\mathrm{NO}_{\mathrm{x}}$ and the other pollutants (Lohmeyer et al., 2002; Amato et al., 2010; Bukowiecki et al., 2010; Gietl et al., 2010). Using this assumption, it is considered that the dilution of other pollutants may be approximated by the dilution of $\mathrm{NO}_{x}$. The wind speed (Fig. 2) and directions during the campaign varied between 0 and $7.6 \mathrm{~m} / \mathrm{s}$, with principally the north direction and few times

140 the south and west direction. The temperature varied between 0 and $19{ }^{\circ} \mathrm{C}$ with relative 141 humidity at about $30-99 \%$. The following equation is used to calculate the emission factor for 142 a given pollutant:

$143 E F_{P}=\Delta P \times \frac{E F_{N O x}}{\Delta N O x}$

144 where $E F_{P}$ and $E F_{N O x}$ are the emission factor for pollutant $\mathrm{P}$ and $\mathrm{NO}$, respectively, given in 145 mass or number of particles per vehicle per kilometer (\#/veh/km or $\mu \mathrm{g} / \mathrm{veh} / \mathrm{km}) . \Delta P$ and $146 \triangle N O x$ are the difference of concentrations between background and traffic sites for 147 pollutant $\mathrm{P}$ and $\mathrm{NO}_{\mathrm{x}}$ respectively. The emission factors for $\mathrm{NO}_{\mathrm{x}}$ used in the equation (1) were 148 obtained using COPERT 4 (COmputer Programme to calculate Emissions from Road 149 Transport) for each time step (one-hour period) with the corresponding fleet composition 150 characterized at the same time step. For urban driving conditions, COPERT 4 estimates a $\mathrm{NO}_{\mathrm{X}}$ emission that takes into account cold and hot emissions. 
For all cartridges, the sampling time is one hour to have enough material for chemical

analysis. For $\mathrm{PN}$ and $\mathrm{BC}$, the data resolution is 1 second. However, in order to be able to analyze the emission factors with the fleet for all measured pollutants, the PN and BC measurement were averaged in one-hour period, corresponding to the cartridge sampling time. In addition, the $\mathrm{NO}_{\mathrm{x}}$ concentrations used for $\Delta \mathrm{NO}_{\mathrm{x}}$ in Equation 1 are given as a 15minute average concentration. It is therefore impossible to go below this 15 -minute time step for calculating emission factors.

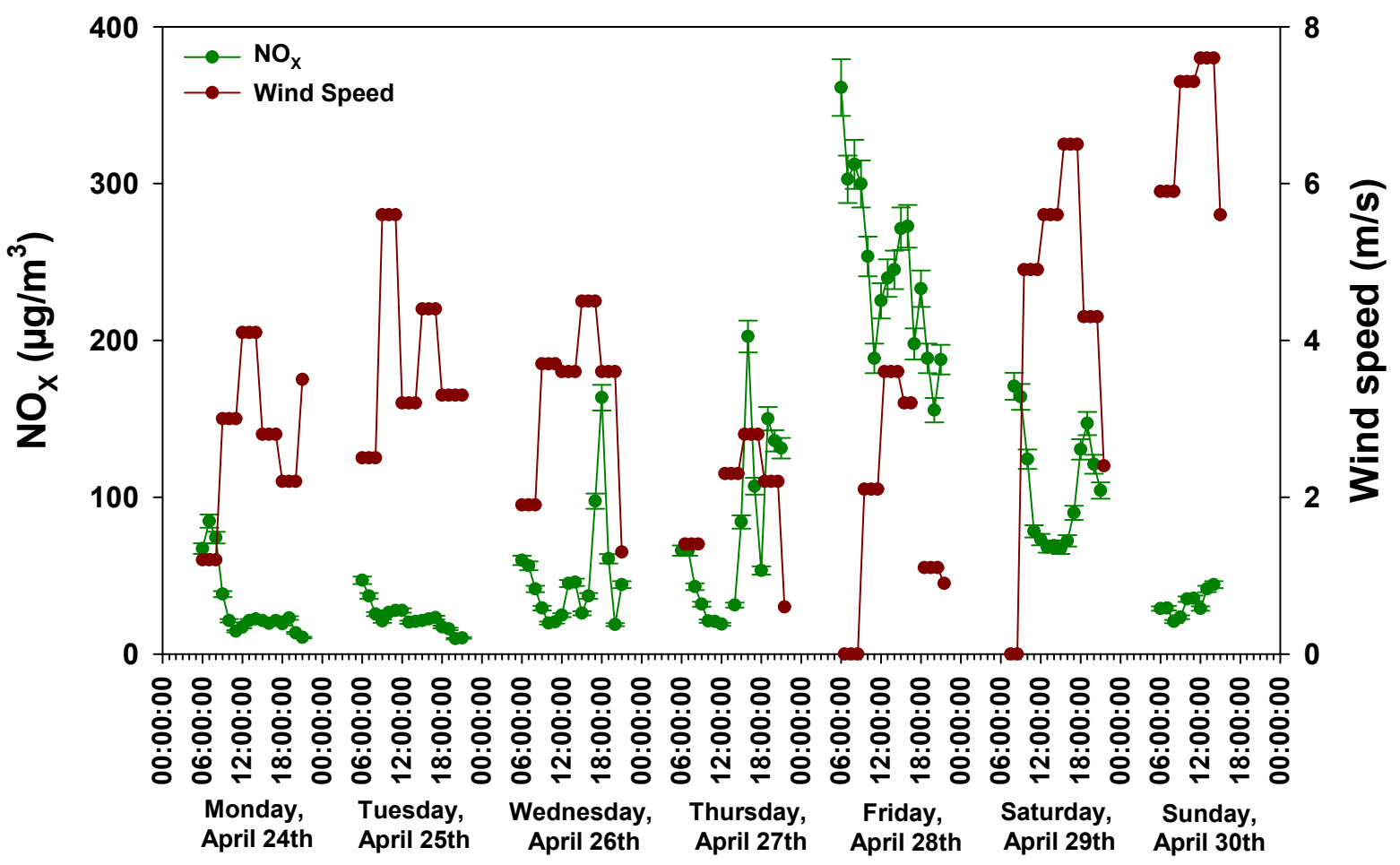

Fig. 2. Time profiles of $\mathrm{NO}_{x}$ concentration and wind speed on the measurement week.

2.5 ANOVA Analysis

The analysis of variance (ANOVA) is a statistical technique for assessing the differences 
alternative hypothesis considers that there is at least one significant difference among the

167 groups. For the ANOVA test, the F-ratio and associated probability value ( $p$-value) are 168 calculated. If the p-value associated with the $\mathrm{F}$ is smaller than 0.05 , then the $\mathrm{HO}$ is rejected 169 and the alternative hypothesis (H1) is retained (Fanelli et al., 2018) and this implies that the 170 groups have a significant impact on emissions (Wildt and Ahtola, 1978). It can be concluded 171 that the means of all groups are not equal and we can determine which groups are different 172 from others.

173 In this work, ANOVA was performed by SPAD (data analysis and data mining software) to between Euro 4 and Euro 6.

\section{Results and Discussion}

\subsection{Fleet Composition}

The number of vehicles was characterized during the measurement on the traffic site. A total of 140,076 vehicles drove along the boulevard during the seven-day measurement period. Many vehicles were registered twice or more times during the week. The number of unique vehicles after removing these duplicates is 57,220 . The number of vehicles varied between 21,147 and 23,401 from Monday to Friday. On Saturday and Sunday, 18,763 vehicles and 9,860 vehicles were counted, respectively. The number of vehicles per hour was 
between 200 and 1600 on the weekend with an average number of 900/h. The traffic speed was characterized for each 5 minutes. The average traffic speed for one hour was between 16 and $34 \mathrm{~km} / \mathrm{h}$ on all five weekdays and 21 and $38 \mathrm{~km} / \mathrm{h}$ on the weekend (

(a)

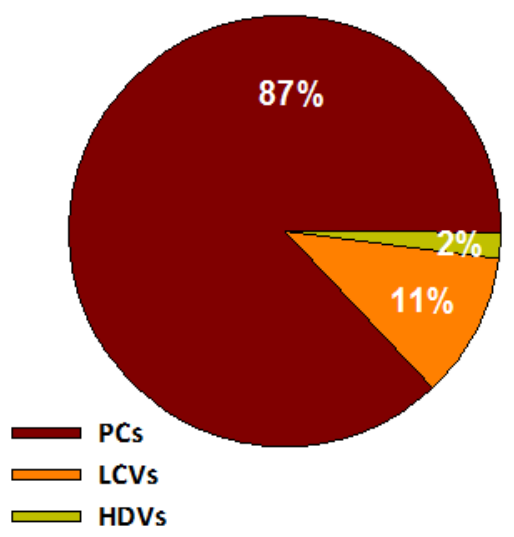

(b)

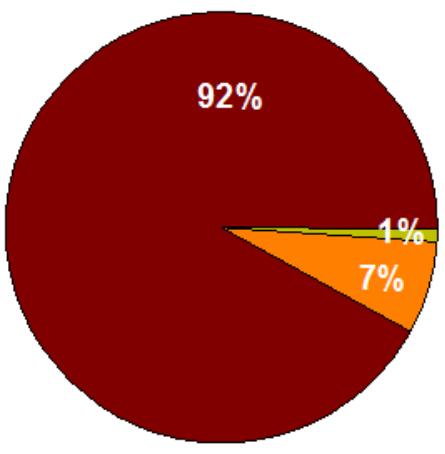

(c)

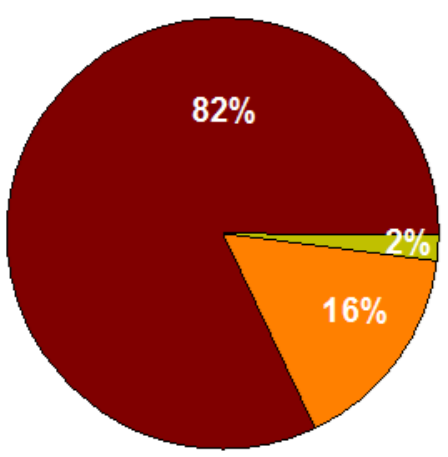

191

192

193

Fig. 3. Weekdays (a) and weekend (b) characterization of the fleet composition during the measurement campaign. 2017 composition of the French fleet (c).

Furthermore, the fleet composition characterized during the measurement campaign was composed of $87 \%$ passenger cars (PCs), $11 \%$ light commercial vehicles (LCVs), and $2 \%$ heavy-duty vehicles (HDVs) on weekdays. On the weekend, it consisted of 92\% PCs, 7\% LCVs, and $1 \%$ HDVs. The number of LCVs and HDVs decreased over the weekend, particularly on Sundays. According to André et al. (2014), the entire French fleet was composed of $82 \%$ PCs, 16\% LCVs, and 2\% HDVs in 2017 (Fig. 3). The comparison between this study and the French fleet composition shows the slightly higher percentage of PCs and the slightly lower percentage of LCVs. These differences are explained by the fact that the measurements were conducted in an urban environment, where LCV and HDV traffic is generally lower. 
(a)

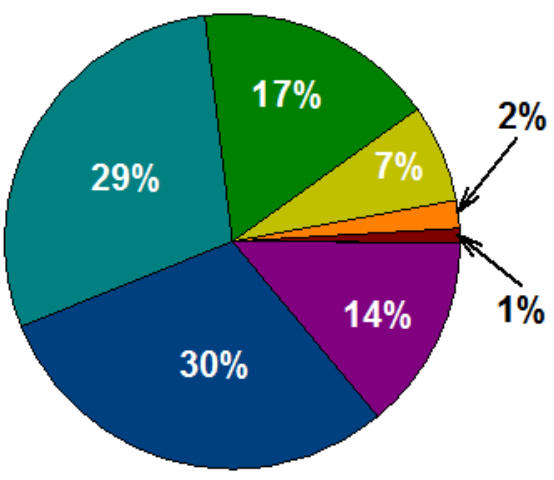

(b)

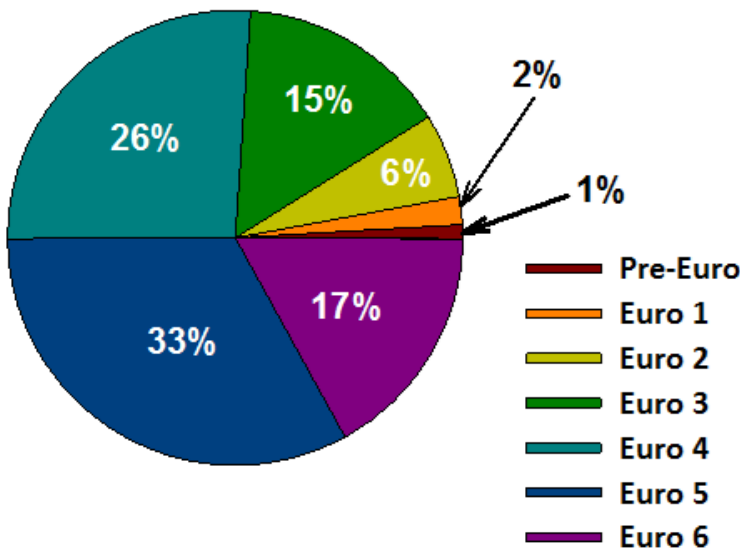

203

204

205

206

207

208

209

210

211

212

213

214

Fig. 4. Distribution of the various Euro emission standards for PCs (a) during the measurement campaign and (b) for the 2017 French fleet.

The distribution of the various Euro emission standards for PCs during the measurements was 14\% Euro 6, 30\% Euro 5, 29\% Euro 4, 17\% Euro 3, 7\% Euro 2, 2\% Euro 1, and 1\% preEuro vehicles (Fig. 4a). This distribution is consistent with André et al. (2014), who estimated the PCs French fleet composed 17\% Euro 6, 33\% Euro 5, 26\% Euro 4, 15\% Euro 3, 6\% Euro 2, 2\% Euro 1, and 1\% pre-Euro in 2017 (Fig. 4b). As regards drive technology systems, the observed PC fleet was composed of $68 \%$ diesel vehicles, $30 \%$ gasoline vehicles, and $2 \%$ other such as gasoline or diesel hybrid vehicles, electric vehicles, gasoline/compressed natural gas and gasoline/liquefied petroleum gas vehicles. The LCV fleet was composed of $97 \%$ diesel vehicles. For the HDVs, all the trucks were powered by diesel engines and all the buses were natural gas combustion or other gaseous hydrocarbons.

\subsection{Estimation of Global Fleet Emission Factors}

The global fleet emission factors for PN, BC, carbonyl compounds, BTEX, alkanes, $\mathrm{NO}_{\mathrm{X}}$ concentrations, number of vehicles, and traffic speeds are presented in Fig. 5 as a function of the measurement time and day on the traffic site. The average emission factor of one 
vehicle (equation (1)) has been multiplying by the vehicle number that gives us the pollutant

221

222

223

224

225

226

227

228

229

230

231

232

233

234

235

236

237

238

239

240

241

242

243

emission factors for a global fleet, over the one-hour measurement period. This allows us to study the pollutant emissions in relation with the current traffic.

The particle number emission factors varied between $2 \times 10^{16}$ and $9.6 \times 10^{17} \# / \mathrm{km}$ on five weekdays and between $2.3 \times 10^{16}$ and $4.6 \times 10^{17} \# / \mathrm{km}$ on the weekend. The $\mathrm{BC}$ emission factors varied between $2.4 \times 10^{9}$ and $2.4 \times 10^{11} \mathrm{ng} / \mathrm{km}$ on weekdays and between $6.6 \times 10^{9}$ and $1.2 \times 10^{11} \mathrm{ng} / \mathrm{km}$ on the weekend. The emission factors for carbonyl compounds varied between $2 \times 10^{4}$ and $2.4 \times 10^{6} \mu \mathrm{g} / \mathrm{km}$ on weekdays and between $2.7 \times 10^{3}$ and $4.9 \times 10^{5} \mu \mathrm{g} / \mathrm{km}$ on the weekend. The hexanal emission factors ranged between $2.3 \times 10^{3}$ and $4.1 \times 10^{5} \mu \mathrm{g} / \mathrm{km}$ on weekdays and between $1.5 \times 10^{4}$ and $3.2 \times 10^{5} \mu \mathrm{g} / \mathrm{km}$ on the weekend. For the three alkanes, the emission factors were between $1.2 \times 10^{4}$ and $7.1 \times 10^{6} \mu \mathrm{g} / \mathrm{km}$ on weekdays and between $5.3 \times 10^{3}$ and $2 \times 10^{6} \mu \mathrm{g} / \mathrm{km}$ on the weekend. The BTEX emission factors ranged between $5.4 \times 10^{3}$ and $3.3 \times 10^{6} \mu \mathrm{g} / \mathrm{km}$ on weekdays and between $6.3 \times 10^{4}$ and $5.1 \times 10^{6} \mu \mathrm{g} / \mathrm{km}$ on the weekend. The missing points for VOCs are either pollutant quantities sampled on the cartridges below their quantification limit; or negative values by subtracting the background value.

The urban background concentrations for the pollutants used in the equation (1) were measured on the urban background site used by the air quality association "Air Pays de la Loire". This background site is not affected by road traffic emissions, the measured $\mathrm{NO}_{\mathrm{x}}, \mathrm{PN}$ and $\mathrm{BC}$ concentrations vary little on the different measurement time (16h/day during 4 days) (between 3200 and $4800 \# / \mathrm{cm}^{3}$ for $\mathrm{PN}$, between 400 and $700 \mathrm{ng} / \mathrm{m}^{3}$ for $\mathrm{BC}$, and between 5 and $50 \mu \mathrm{g} / \mathrm{m}^{3}$ for $\mathrm{NO}_{\mathrm{x}}$ ) and provides a general background concentration with all different sources. The subtraction in the equation (1) allows removing only the general back ground levels but not the local background levels. This might induce a potential bias with an over 
244 estimation of EF for PN and other pollutants if the local background levels are higher than

245 general background levels. The local background levels could also be measured when there 246 is no traffic. However, depending on the weather conditions, especially the wind speeds, the 247 accumulation phenomena under no traffic condition might also induce a potential bias on 248 our measurement. The first point in the morning (at around 6:00 a.m.) was taken as the 249 background level at the traffic site. Using this local background levels, the emission factors of $250 \mathrm{PN}$ and $\mathrm{BC}$ are respectively between $5 \times 10^{15}$ and $9 \times 10^{17} \# / \mathrm{km}$ and $1.2 \times 10^{8}$ and $2512.3 \times 10^{11} \mathrm{ng} / \mathrm{km}$. The local background values induce an underestimation of 4 and 20 times 252 for PN and BC comparing to the 'Air Pays de la Loire' background site, but only for low 253 emission period. These background values do not induce a significant difference at high 254 emission period for both PN and BC. Overall, if we use the local background value, it induced 255 an average underestimation around $30 \%$ for all period of measurement.

In general, the highest emission factors were measured between 7:00 a.m. and 257 10:00 a.m. and between 5:00 p.m. and 8:00 p.m. on all five weekdays. For the Saturday, the 258 highest emission factors were measured between 10:00 a.m. and 1:00 p.m. and between 259 5:00 p.m. and 8:00 p.m. For the Sunday, between 6:00 a.m. and 3:00 p.m., high emission 260 factors were measured for carbonyl compounds, BTEX and alkanes. The higher emission 261 factors measured in the morning can be explained by vehicle cold start, which emits large 262 amounts of pollutants such as BC, PN, BTEX, and carbonyl compounds (Westerholm et al., 263 1996; Joumard et al., 2000; Sluder et al., 2000; Caplain et al., 2006; Louis et al., 2016; 264 Martinet et al., 2017). 

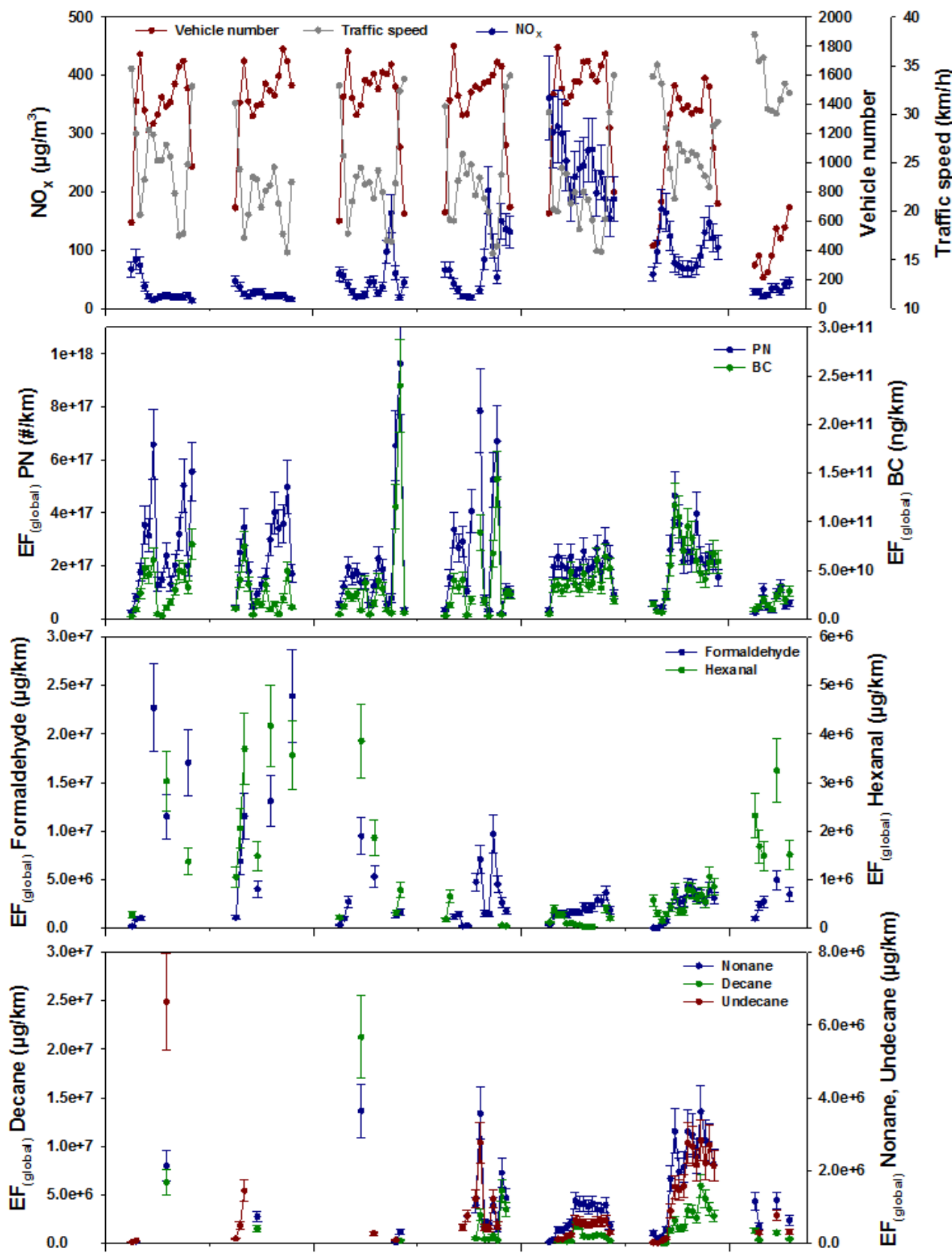

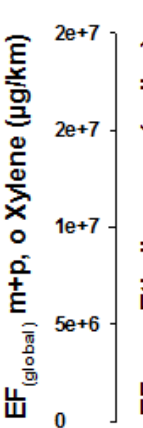

0.0 重要

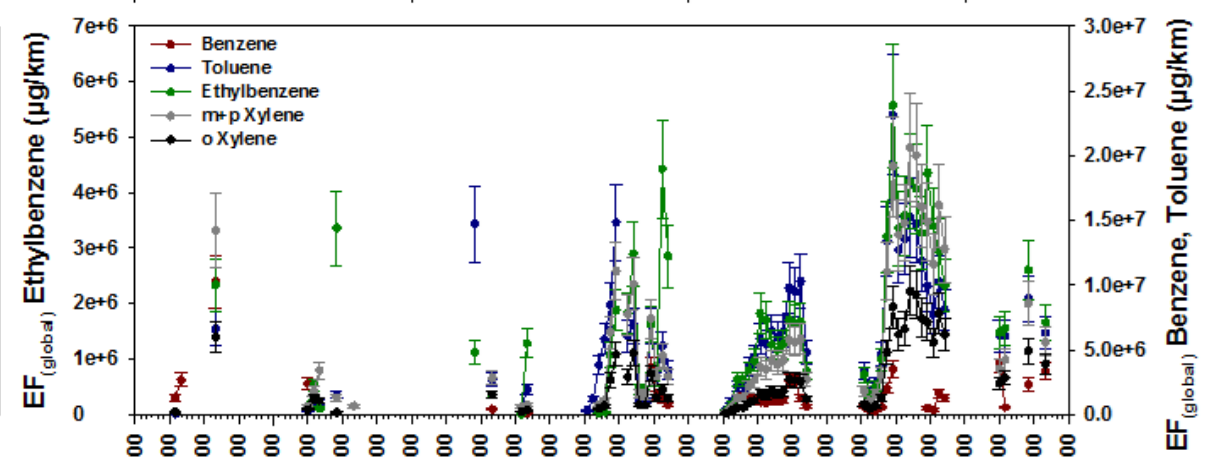

Fig. 5. Global fleet emission factors for PN, BC, carbonyl compounds, BTEX, alkanes, $\mathrm{NO}_{\mathrm{x}}$ concentrations, number of vehicles, and traffic speeds as a function of the time and day of measurement on the traffic site. 
The PN and BC emission factors showed a good correlation, following the same tendency

\section{9}

during the week of measurements (Fig. 5). Apart from Tuesday afternoon between 2:00 p.m. and 8:00 p.m., the PN emission factors did not follow the same tendency as the BC emission factors. The emission factor values for BC decreased while those for PN increased sharply.

This could imply that the particle number emissions measured during this afternoon were not due to road traffic (See Section below).

\subsection{PN Concentration and Size Distribution Time Profiles}

The number of vehicles, $\mathrm{BC}, \mathrm{NO}_{\mathrm{x}}$ and $\mathrm{PN}$ for three size ranges $([0-50] \mathrm{nm},[50-100] \mathrm{nm}$, and [100-500] $\mathrm{nm}$ ) concentrations were followed from Monday (April 24 ${ }^{\text {th }}$ ) to Sunday (April $\left.30^{\text {th }}\right)$, which show the similar results in general for the five weekdays, except for Tuesday afternoon. Fig. 6 shows the time profiles of $\mathrm{NO}_{x}, \mathrm{BC}, \mathrm{PN}$ concentrations and vehicles number on Monday, Tuesday and Wednesday. Concentration peaks of $\mathrm{BC}, \mathrm{PN}$ and $\mathrm{NO}_{\mathrm{x}}$ was observed over a short period between 7:00 a.m. and 9:00 a.m. on weekdays corresponding to morning rush-hour traffic (See Section 3.2).

Moreover, Fig. 6 shows a large peak for PN with size range [0-50] nm between 2:00 p.m. and 8:00 p.m. on Tuesday that is not correlated with $\mathrm{BC}, \mathrm{NO}_{\mathrm{x}}$ and $\mathrm{PN}$ size ranges [50-100] nm and [100-500] nm. Since $\mathrm{NO}_{x}$ and $\mathrm{BC}$ are considered as traffic tracers (Pant et al., 2013), which might indicates that the [0-50] nm PN on Tuesday afternoon is not generated by the road traffic. 


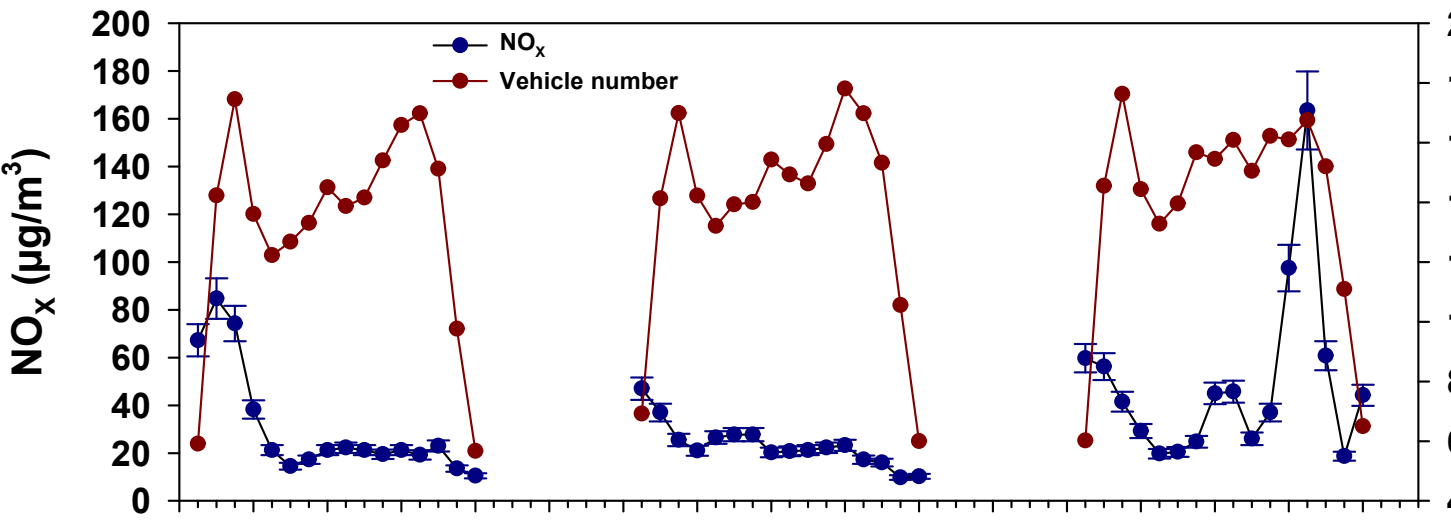

2000

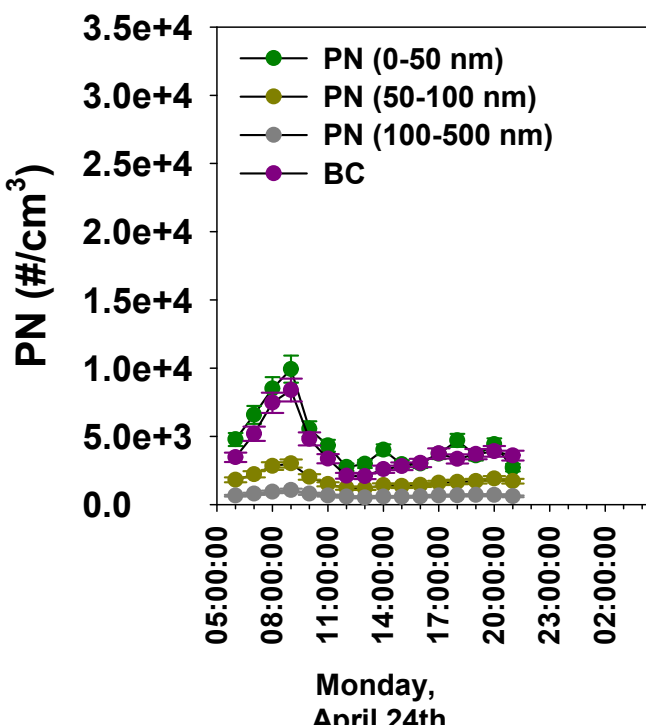

April 24th

Fig. 6. Time profiles of $\mathrm{NO}_{x}$ concentration and number of vehicles and $\mathrm{PN}$ and $\mathrm{BC}$ concentrations on Monday, Tuesday and

Wednesday.

\subsection{ANOVA Analysis of Global Fleet Emission Factors}

The pollutant emission factors for a global fleet, over the one-hour measurement period,

have been analyzed by ANOVA statistical analysis to investigate impact of fleet composition

on measured pollutant emissions (Table 1). The emission factors were analyzed with 6

294 categories: number of HDVs (0 to 43 with groups of every $10 \mathrm{HDVs}$ ), percentage of diesel PCs

295 between pre-Euro to Euro 3 ( 5 to $25 \%$ with 5\% interval), percentage of Euro 4 diesel PCs (10

296 to $30 \%$ with 5\% interval), percentage of diesel PCs Euro 5 and Euro 6 (15 to 35\% with 5\%

297 interval), percentage of gasoline PCs between pre-Euro and Euro 3 standard (5 to $15 \%$ with 
5\% interval) and percentage of gasoline PCs between Euro 4 and Euro 6 (5 to 25\% with 5\%

interval). The groups of variables for passenger cars have been made according to the 300 implementation of new after-treatment or engine technologies. For diesel vehicles, the diesel particle filter (DPF), which significantly reduces PN and BC emissions, is considered as variables. Thus, the first category includes the percentage of pre-Euro to Euro 3 diesel vehicles that are not equipped with DPF; the second category includes the percentage of Euro 4 diesel vehicles that are partially equipped with DPF; and the last category includes the percentage of Euro 5 and Euro 6 diesel vehicles that are all equipped with DPF. For gasoline vehicles, the first category therefore includes the percentage of gasoline vehicles from pre-

Euro to Euro 3 standards, all of which have indirect injection engines; and the second category includes the percentage of gasoline vehicles from Euro 4 to Euro 6 standards, as the introduction of direct injection engines has begun on Euro 4 standard vehicles. Moreover, for ANOVA analysis, the fleet composition has been classed by groups (different gaps of vehicle number or percentage) to investigate their impact on emissions. Each group has to contain enough samples to be significant and not too large to have a good sensibility. Tuesday afternoon PN data have not been taken into account because of its strange behavior show in section 3.3.

For a result of the ANOVA analysis to be significant, the $p$-value must be $\leq 0.05$, which is called a "significant result" in Table 1. However, to increase the power of the ANOVA analysis, it is possible to consider that a result with a p-value between 0.05 and 0.1 are significant, which is called "result considered as significant" in Table 1, but with a great uncertainty. This analysis should be read with a special attention because they might also

320 indicate that the impacts of the analyzed group on emission could be significant but not clearly significant. 
Table 1

323 Results of the ANOVA analysis for the effect of the fleet composition on the emission factors

\begin{tabular}{|c|c|c|c|c|c|}
\hline \multirow{2}{*}{$\begin{array}{c}\text { Fleet } \\
\text { composition }\end{array}$} & \multirow{2}{*}{ Pollutants } & \multirow{2}{*}{ Unit } & \multirow{2}{*}{ p-value } & \multicolumn{2}{|c|}{ Groups having a significant impact } \\
\hline & & & & Negative impact & Positive impact \\
\hline & PN & $\# / \mathrm{km}$ & 0.6 & -- & -- \\
\hline & BC & $\mathrm{ng} / \mathrm{km}$ & 0.2 & -- & -- \\
\hline & Formaldehyde & $\mu \mathrm{g} / \mathrm{km}$ & 0.2 & -- & -- \\
\hline & Hexanal & $\mu \mathrm{g} / \mathrm{km}$ & 0.6 & -- & -- \\
\hline & Benzene & $\mu \mathrm{g} / \mathrm{km}$ & 0.6 & -- & -- \\
\hline Number of & Toluene & $\mu \mathrm{g} / \mathrm{km}$ & $0.004^{*}$ & $20-30 ; 30-40$ & $10-20$ \\
\hline \multirow[t]{8}{*}{ HDVs } & Ethylbenzene & $\mu \mathrm{g} / \mathrm{km}$ & $0.04^{*}$ & $30-40$ & $0-10 ; 10-20$ \\
\hline & $m+p-X y l e n e$ & $\mu \mathrm{g} / \mathrm{km}$ & 0.2 & -- & -- \\
\hline & o-Xylene & $\mu \mathrm{g} / \mathrm{km}$ & 0.1 & -- & -- \\
\hline & Nonane & $\mu \mathrm{g} / \mathrm{km}$ & 0.5 & -- & -- \\
\hline & Decane & $\mu \mathrm{g} / \mathrm{km}$ & 0.4 & -- & -- \\
\hline & Undecane & $\mu \mathrm{g} / \mathrm{km}$ & 0.7 & -- & -- \\
\hline & PN & $\# / \mathrm{km}$ & $0.08^{* *}$ & $15-20 \%$ & $10-15 \%$ \\
\hline & BC & $\mathrm{ng} / \mathrm{km}$ & 0.6 & -- & -- \\
\hline $\begin{array}{l}\text { Percentage } \\
\text { of diesel PCs }\end{array}$ & Formaldehyde & $\mu \mathrm{g} / \mathrm{km}$ & 0.3 & -- & -- \\
\hline between & Hexanal & $\mu \mathrm{g} / \mathrm{km}$ & 0.2 & -- & -- \\
\hline \multirow{2}{*}{$\begin{array}{l}\text { between } \\
\text { pre-Euro to }\end{array}$} & Benzene & $\mu \mathrm{g} / \mathrm{km}$ & 0.6 & -- & -- \\
\hline & \multicolumn{5}{|c|}{ Euro 3} \\
\hline & Ethylbenzene & $\mu \mathrm{g} / \mathrm{km}$ & $0.07^{* *}$ & $10-15 \%$ & $15-20 \%$ \\
\hline & $m+p-X y l e n e$ & $\mu \mathrm{g} / \mathrm{km}$ & $0.02^{*}$ & $10-15 \%$ & $15-20 \%$ \\
\hline & o-Xylene & $\mu \mathrm{g} / \mathrm{km}$ & $0.02^{*}$ & $10-15 \%$ & $15-20 \%$ \\
\hline
\end{tabular}




\begin{tabular}{|c|c|c|c|c|c|}
\hline & Nonane & $\mu \mathrm{g} / \mathrm{km}$ & 0.1 & -- & -- \\
\hline & Decane & $\mu \mathrm{g} / \mathrm{km}$ & 0.9 & -- & -- \\
\hline & Undecane & $\mu \mathrm{g} / \mathrm{km}$ & 0.7 & -- & -- \\
\hline & PN & $\# / \mathrm{km}$ & 0.1 & -- & -- \\
\hline & $B C$ & $\mathrm{ng} / \mathrm{km}$ & $0.001^{*}$ & $10-15 \% ; 15-20 \%$ & $20-25 \% ; 25-30 \%$ \\
\hline & Formaldehyde & $\mu \mathrm{g} / \mathrm{km}$ & $0^{*}$ & $20-25 \% ; 25-30 \%$ & $10-15 \% ; 15-20 \%$ \\
\hline & Hexanal & $\mu \mathrm{g} / \mathrm{km}$ & 0.7 & -- & -- \\
\hline Percentage & Benzene & $\mu \mathrm{g} / \mathrm{km}$ & 0.3 & -- & -- \\
\hline of diesel PCs & Toluene & $\mu \mathrm{g} / \mathrm{km}$ & 0.1 & -- & -- \\
\hline Euro 4 & Ethylbenzene & $\mu \mathrm{g} / \mathrm{km}$ & $0.02^{*}$ & $15-20 \%$ & $20-25 \%$ \\
\hline \multirow[t]{7}{*}{ standard } & $m+p-X y l e n e$ & $\mu \mathrm{g} / \mathrm{km}$ & $0.04^{*}$ & $15-20 \%$ & $20-25 \%$ \\
\hline & o-Xylene & $\mu \mathrm{g} / \mathrm{km}$ & $0.02 *$ & $15-20 \%$ & $20-25 \%$ \\
\hline & Nonane & $\mu \mathrm{g} / \mathrm{km}$ & 0.3 & -- & -- \\
\hline & Decane & $\mu \mathrm{g} / \mathrm{km}$ & 0.9 & -- & -- \\
\hline & Undecane & $\mu \mathrm{g} / \mathrm{km}$ & 0.6 & -- & -- \\
\hline & PN & $\# / \mathrm{km}$ & $0.006^{*}$ & $30-35 \%$ & $20-25 \%$ \\
\hline & $\mathrm{BC}$ & $\mathrm{ng} / \mathrm{km}$ & 0.2 & -- & -- \\
\hline Percentage & Formaldehyde & $\mu \mathrm{g} / \mathrm{km}$ & $0.06^{* *}$ & $15-20 \%$ & $30-35 \%$ \\
\hline of diesel PCs & Hexanal & $\mu \mathrm{g} / \mathrm{km}$ & 0.3 & -- & -- \\
\hline between & Benzene & $\mu \mathrm{g} / \mathrm{km}$ & $0.07^{* *}$ & $15-20 \%$ & $30-35 \%$ \\
\hline Euro 5 to & Toluene & $\mu \mathrm{g} / \mathrm{km}$ & 0.2 & -- & -- \\
\hline Euro 6 & Ethylbenzene & $\mu \mathrm{g} / \mathrm{km}$ & 0.2 & -- & -- \\
\hline \multirow[t]{3}{*}{ standard } & $m+p-X y l e n e$ & $\mu \mathrm{g} / \mathrm{km}$ & 0.1 & -- & -- \\
\hline & o-Xylene & $\mu \mathrm{g} / \mathrm{km}$ & $0.06^{* *}$ & $15-20 \%$ & $30-35 \%$ \\
\hline & Nonane & $\mu \mathrm{g} / \mathrm{km}$ & 0.2 & -- & -- \\
\hline
\end{tabular}




\begin{tabular}{|c|c|c|c|c|c|}
\hline & Decane & $\mu \mathrm{g} / \mathrm{km}$ & 0.6 & -- & -- \\
\hline & Undecane & $\mu \mathrm{g} / \mathrm{km}$ & $0.007^{*}$ & $15-20 \%$ & $30-35 \%$ \\
\hline & PN & $\# / \mathrm{km}$ & 0.5 & -- & -- \\
\hline & $\mathrm{BC}$ & $\mathrm{ng} / \mathrm{km}$ & 0.7 & -- & -- \\
\hline & Formaldehyde & $\mu \mathrm{g} / \mathrm{km}$ & 0.9 & -- & -- \\
\hline & Hexanal & $\mathrm{ug} / \mathrm{km}$ & 0.07 & -- & -- \\
\hline t gasomite & Benzene & $\mu \mathrm{g} / \mathrm{km}$ & 0.4 & -- & -- \\
\hline PCs & & & & & \\
\hline between & Toluene & $\mu \mathrm{g} / \mathrm{km}$ & $0.07^{* *}$ & $5-10 \%$ & $10-15 \%$ \\
\hline & Ethylbenzene & $\mu \mathrm{g} / \mathrm{km}$ & $0.004^{*}$ & $5-10 \%$ & $10-15 \%$ \\
\hline & $\mathrm{m}+\mathrm{p}$-Xylene & $\mu \mathrm{g} / \mathrm{km}$ & $0.007^{*}$ & $5-10 \%$ & $10-15 \%$ \\
\hline Euro 3 & & & & & \\
\hline & o-Xylene & $\mu \mathrm{g} / \mathrm{km}$ & $0.02^{*}$ & $5-10 \%$ & $10-15 \%$ \\
\hline & Nonane & $\mu \mathrm{g} / \mathrm{km}$ & 0.2 & -- & -- \\
\hline & Decane & $\mu \mathrm{g} / \mathrm{km}$ & 0.9 & -- & -- \\
\hline & Undecane & $\mu \mathrm{g} / \mathrm{km}$ & 0.7 & -- & -- \\
\hline & $\mathrm{PN}$ & $\# / \mathrm{km}$ & $0.004^{*}$ & $5-10 \%$ & $20-25 \%$ \\
\hline & $\mathrm{BC}$ & $\mathrm{ng} / \mathrm{km}$ & $0^{*}$ & $5-10 \% ; 10-15 \%$ & $20-25 \%$ \\
\hline Percentage & Formaldehyde & $\mu \mathrm{g} / \mathrm{km}$ & 0.5 & -- & -- \\
\hline of gasoline & Hexanal & $\mu \mathrm{g} / \mathrm{km}$ & 0.6 & -- & -- \\
\hline PCs & Benzene & $\mu \mathrm{g} / \mathrm{km}$ & 0.4 & -- & -- \\
\hline between & Toluene & $\mu \mathrm{g} / \mathrm{km}$ & 0.3 & -- & -- \\
\hline Euro 4 to & Ethylbenzene & $\mu \mathrm{g} / \mathrm{km}$ & 0.1 & -- & -- \\
\hline Euro 6 & $m+p-X y l e n e$ & $\mu \mathrm{g} / \mathrm{km}$ & 0.1 & -- & -- \\
\hline standard & o-Xylene & $\mu \mathrm{g} / \mathrm{km}$ & 0.1 & -- & -- \\
\hline & Nonane & $\mu \mathrm{g} / \mathrm{km}$ & 0.3 & -- & -- \\
\hline & Decane & $\mu \mathrm{g} / \mathrm{km}$ & 0.5 & -- & -- \\
\hline
\end{tabular}


${ }^{*}$ Significant results

** Results considered as significant

-- No results

For BC, the groups of "20-25\%" and "25-30\%" Euro 4 diesel PCs and "20-25\%" gasoline PCs between Euro 4 to Euro 6 have a significant positive impact on the emissions. This observation indicates that higher percentage of these two categories present in the fleet induces more BC emission. For the gasoline PCs between Euro 4 to Euro 6, the group "20$25 \% "$ has also a significant positive impact on the PN emissions. The positive impact of gasoline PCs between Euro 4 and Euro 6 on the PN and BC emissions can be explained by the introduction of direct injection technology on certain gasoline vehicles, which induces more $\mathrm{PN}$ and $\mathrm{BC}$ emissions than multipoint injection gasoline vehicles. These emissions could reach the level of some diesel vehicles without a particulate filter (Liang et al., 2013, Martinet et al., 2017).

The percentage of diesel and gasoline PCs between pre-Euro and Euro 3 has a significant positive impact on toluene, ethylbenzene and $\mathrm{m}+\mathrm{p}$ - and o-xylene emission factors, more 343 ethylbenzene, $m+p-x y l e n e$ and o-xylene. The group "10-15\%" of Pre-Euro to Euro 3 gasoline induces 1.2, 1.4, 1.3 and 1.3 times higher emission respectively for toluene, ethylbenzene, $\mathrm{m}+\mathrm{p}-\mathrm{xylene}$ and o-xylene. Moreover, the group "20-25\%" of diesel Euro 4 PCs has also a positive impact on ethylbenzene and $\mathrm{m}+\mathrm{p}$ - and o-xylene emission factors, $1.4,1.4$ and 1.5 
times higher respectively comparing to the average emission factors. For the analyses on the

number of HDVs, emission factors estimated in the weekend have not been taken into account because of the HDV driving ban. The Table 1 showed that the impact of the number

of HDVs on pollutant emission does not show a significant positive impact. This observation might be explained on one side by the small percentage of HDVs in the fleet (0 to $43 \mathrm{HDVs}$ per hour); and on the other side by the low HDVs emission since $80 \%$ of these HDVs are recent vehicles ( $\geq$ Euro 4).

\subsection{Emission Factors Per Vehicle and Comparison with Other Studies}

In this section, the average emission factors calculated by equation (1) were used (\# or mass $/ v e h / \mathrm{km}$ ) in order to compare with other studies. Fig. 7 shows the box-and-whisker plot for these average emission factors per vehicle for carbonyl compounds, BTEX, alkanes, PN, and $\mathrm{BC}$. In these plots, the boxes contain $50 \%$ of the emission factors around the median (black line in the box). The upper and lower halves of the boxes represent respectively the $75^{\text {th }}$ and $25^{\text {th }}$ percentiles and the whiskers represent the $90^{\text {th }}$ and $10^{\text {th }}$ percentiles. The emission factors that are above or below the whiskers are considered to be atypical values.

Fig. 7 shows the average emission factors per vehicle for $\mathrm{PN}$ and $\mathrm{BC}$, which are between $1.2 \times 10^{13}$ and $8.7 \times 10^{14} \# / \mathrm{km} /$ veh and between $1.7 \times 10^{6}$ and $2.16 \times 10^{8} \mathrm{ng} / \mathrm{km} / \mathrm{veh}$, respectively. For both emission factors, the median is in the middle of the box, which indicates a symmetric distribution. Half the emission factors are between $9.1 \times 10^{13}$ and $1.87 \times 10^{14} \# / \mathrm{km} /$ veh for PN and between $1.1 \times 10^{7}$ and $3.8 \times 10^{7} \mathrm{ng} / \mathrm{km} /$ veh for BC. In addition, the boxes are comparatively short, suggesting that the PN emission factors have a high level of agreement between them, and the $\mathrm{BC}$ emission factors have also a high level of agreement between them. Fig. 7 shows also the average emission factors per vehicle for the 
370 measured VOCs and SVOCs. For all these compounds, the median is in the lower half of the

371 box, which assumes an asymmetric distribution toward the low values. Their emission

373 For each compound, the atypical values are presented by black dots. Here, only the 374 atypical values above the upper whisker limit are further analyzed with the corresponding 375 fleet composition. The emission factors above the upper whisker for $\mathrm{PN}$ and $\mathrm{BC}$ are, 376 respectively, 2.3 to 6.6 times higher and 2.7 to 9.6 times higher compared to the median.

377 The highest emission factor for both corresponds to the same fleet composition with $69 \%$ of 378 LDVs diesel and $58 \%$ of PCs $\leq$ Euro 4 (composition 8 in the Fig. 7) for the Wednesday 379 between 8:00 p.m. and 9:00 p.m. The second highest emission factor for BC and the third 380 highest for PN (composition 7 in the Fig. 7) correspond to the Sunday between 8:00 a.m. and $3819: 00$ a.m. 

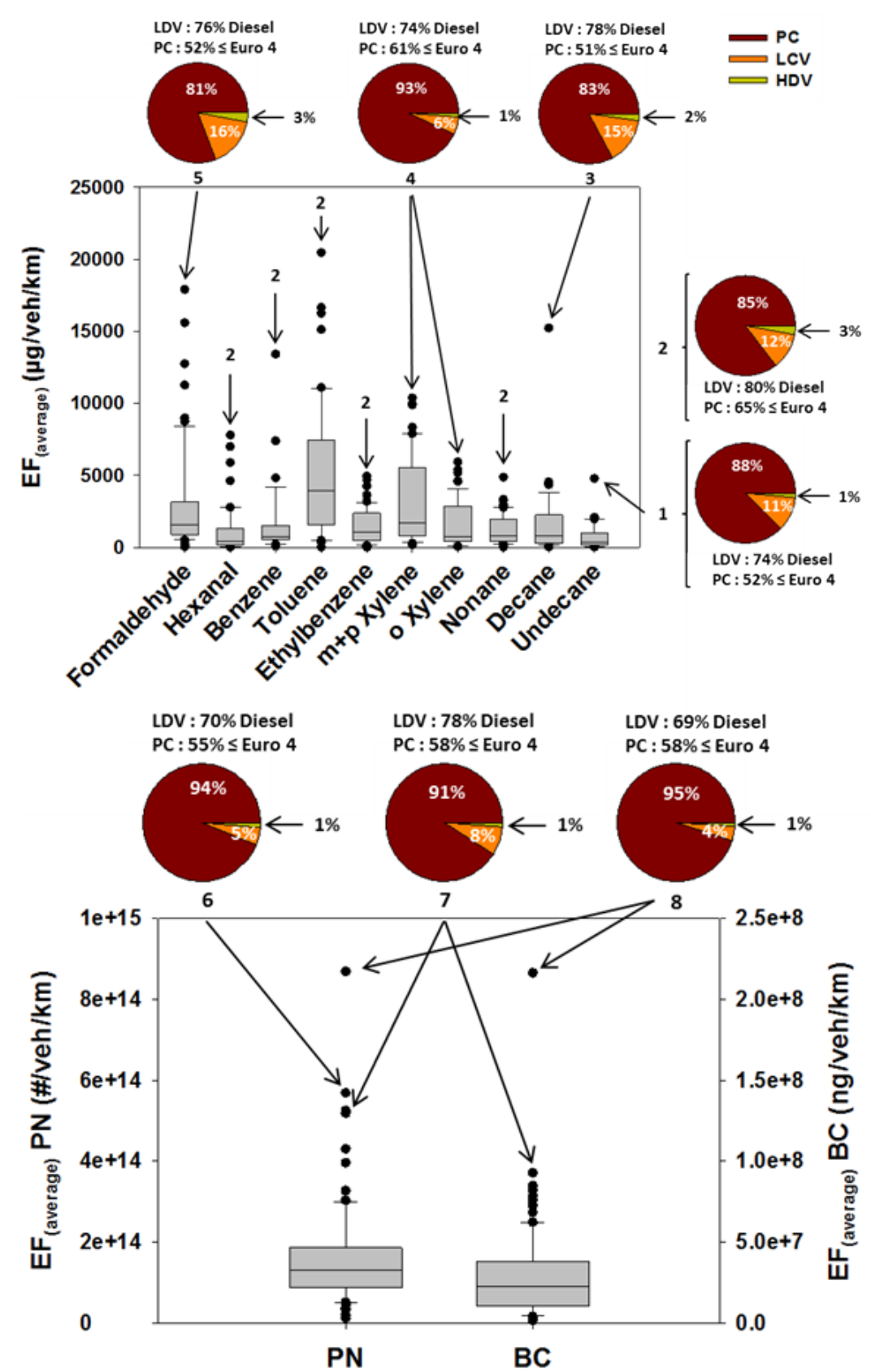

383 Fig. 7. Box-and-whisker plot of the average vehicle emission factors for PN, BC, carbonyl compounds, BTEX and alkanes. 384 Fleet composition of 1: Monday 2:00 - 3:00 p.m.; 2: Sunday 6:00 - 7:00 a.m.; 3: Wednesday 11:00 - 12:00 a.m.; 4: Sunday 385 11:00 - 12:00 a.m.; 5: Monday 11:00 - 12:00 a.m.; 6: Monday 8:00 - 9:00 p.m.; 7: Sunday 8:00 - 9:00 a.m.; 8: Wednesday 8:00 - 9:00 p.m.

The emission factors for carbonyl compounds above the upper whisker are 5 to 11 times higher and 6 to 17 times higher than the median for formaldehyde and hexanal, respectively. For the three alkanes, the emission factors above the upper whisker are 3 to 18 times higher 
compared to their median. The BTEX emission factors above the upper whisker are 1.4 to 8

391 times higher compared to their median. The highest emission factor for hexanal, benzene,

392 toluene, ethylbenzene and nonane correspond to the same fleet composition (composition 2

393 in the Fig. 7) for the Sunday between 6:00 a.m. and 7:00 a.m. We remark that, in this time

394 interval, the fleet composition composed relatively high percentage of LDVs diesel (80\%),

$395 \mathrm{PCs} \leq$ Euro $4(65 \%)$ and HDVs (3\%), which have been showed by the ANOVA analysis to have

significant impacts on emission of these compounds (Table 3). For $m+p$ and o xylene compounds, the highest emission factor corresponds to the fleet composition of the Sunday between 11:00 a.m. and 12:00 a.m. (composition 4 in the Fig. 7), with relatively high percentage of PCs $\leq$ Euro 4. For formaldehyde, the highest emission factor corresponds to the Monday between 11:00 a.m. and 12:00 a.m. (composition 5) with 3\% of HDVs.

Fig. 8 shows the comparison of $\mathrm{PN}, \mathrm{BC}$, formaldehyde and BTEX emission factors estimated in this study and with those estimated during lab bench measurements with Artemis urban driving cycles that is not exactly the same driving condition but might represent the most similar driving condition (average speed from 8.7 to $31.8 \mathrm{~km} / \mathrm{h}$ from congestion to fluid situations) comparing to our traffic site (hourly average speed between 16 and $34 \mathrm{~km} / \mathrm{h}$ ). The detail of bench measurement of Euro 1 to Euro 6 gasoline and diesel PCs were presented in our previous works (Rehn 2013; Louis et al., 2016; Martinet et al., 2017). Moreover, the $P N$ and $B C$ emission factors estimated in this study were also compared with other in-situ studies with similar site characteristics (Ketzel et al., 2003; Gratmonev et al., 2004; Rose et al., 2005; Imhof et al., 2005; Jones et al. 2006; Westerdahl et al., 2009; Krecl et al., 2018).

The emission factors estimated by other in-situ studies are between $5.8 \times 10^{13}$ and 9.3 $\times 10^{14} \# /$ veh/km for $\mathrm{PN}$; and between $1.7 \times 10^{7}$ and $3.5 \times 10^{7} \mathrm{ng} / \mathrm{veh} / \mathrm{km}$ for $\mathrm{BC}$, which are in 
414 the same range as those estimated in this paper (Fig. 8), even fleet compositions are
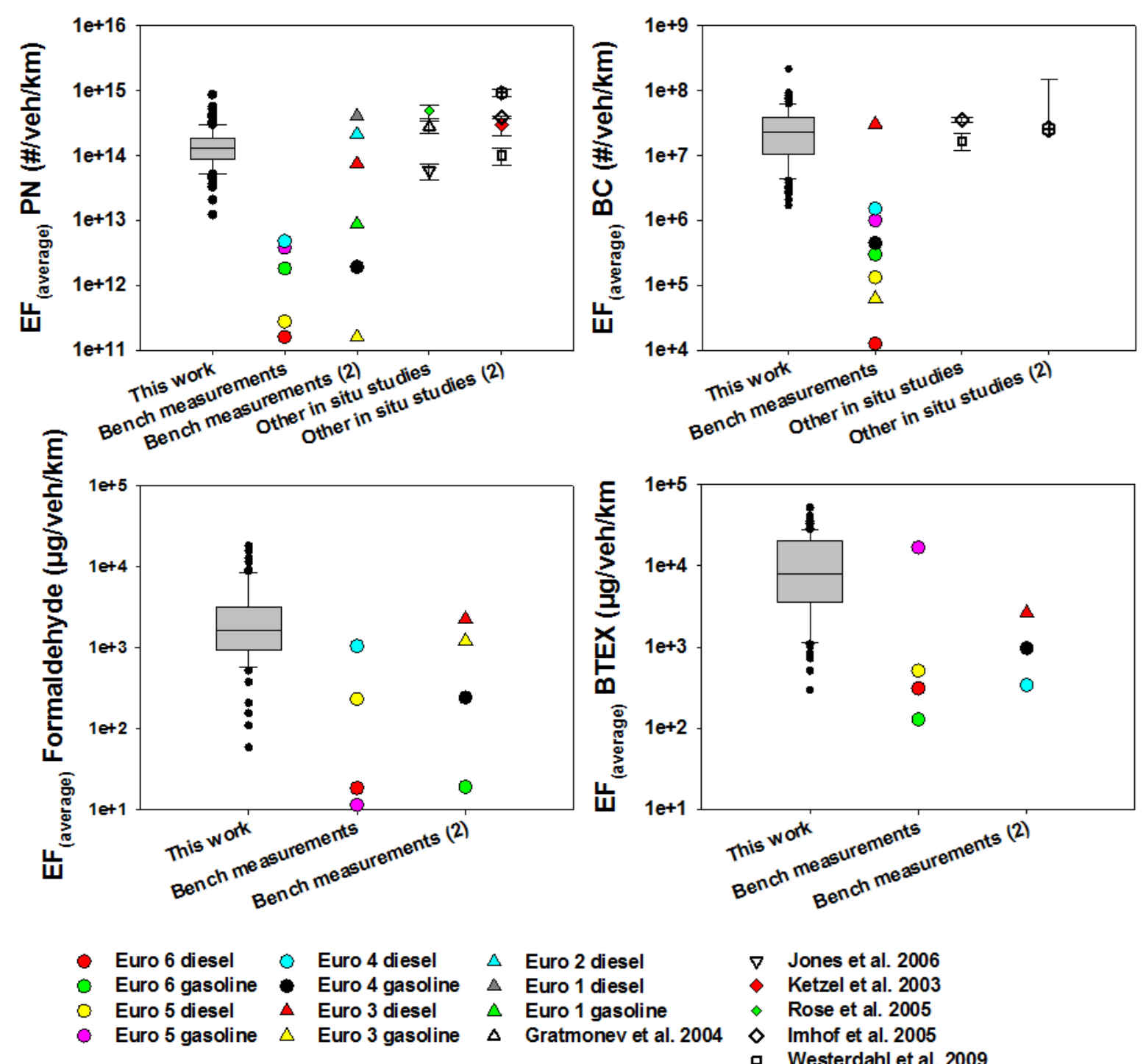

$\nabla$ Jones et al. 2006

$\checkmark \quad$ Ketzel et al. 2003

$\diamond \quad$ Rose et al. 2005

$\diamond \quad$ Imhof et al. 2005

a Westerdahl et al. 2009

Krecl 2018

417 Fig. 8. Comparison of PN, BC, formaldehyde and BTEX emission factors per vehicle in this work with emission factors 418 estimated by bench measurements (Rehn 2013; Louis et al., 2016; Martinet et al., 2017) or by other in-situ studies (Ketzel 419 et al., 2003; Gratmonev et al., 2004; Rose et al., 2005; Imhof et al., 2005; Jones et al., 2006; Westerdahl et al., 2009; Krecl et 420 al., 2018).

421 The PCs emission factors in this work are also compared to the bench measurement 422 (previous work). The bench emission factors of $\mathrm{PN}$ and $\mathrm{BC}$ obtained from diesel vehicles 
without particle filter and gasoline vehicles with direct injection system are in the same 424

range as the box plot. The impact of gasoline with direct injection system and Euro 4 diesel vehicles on PN and BC emission has been observed with ANOVA analysis. However, for the pre-Euro to Euro 3 old diesel vehicles, even they induce a high $\mathrm{BC}$ and PN emission with individual vehicle measurement, their impact on $\mathrm{BC}$ and $\mathrm{PN}$ emission could be considered either as significant but with a great uncertainty or not significant because they are omnipresent in each one-hour period with very closed percentage in the fleet (10 to $20 \%$ ). These in-situ emission factors are also comparable with old HDVs without particle filter (PN emission factors between $5 \times 10^{13}$ and $2 \times 10^{14} \# /$ veh/km) (Giechaskiel et al., 2012), contrary to recent HDVs equipped with DPF that induce lower PN emissions (between $5 \times 10^{10}$ and $2 \times 10^{12}$ \#/veh/km) (Giechaskiel et al., 2018). For fomaldehyde, the emission factors of Euro 3 and Euro 4 diesel and gasoline vehicles are in the same range as the emission factors estimated in this work. More recent Euro 5 and Euro 6 PCs seem to contribute less emission. For BTEX, the Euro 5 gasoline DI vehicle is located above the box that might indicate its high impact on BTEX emission. However, we want to attract special attention here, because only one Euro 5 gasoline DI vehicle data from bench has been provided (Louis et al., 2016). More vehicles for each category should be tested on the chassis bench under similar experimental conditions

\section{Conclusion}

This paper aimed to estimate the emission factors of PN, BC, and several aliphatic, aromatic and carbonyl compounds with a real fleet present on the measurement site. The fleet composition characterized during the measurement campaign was comparable with 
the 2017 French fleet. A total of 140,076 vehicles were counted for seven days with about

21,000 to 23,000 vehicles in the weekdays and 10,000 to 18,000 in the weekend.

The highest emissions were measured during the morning between 7:00 a.m. - 10:00

448 a.m. and during the end of afternoon between 5:00 p.m. - 8:00 p.m. for the weekdays, and 449 between 10:00 a.m. - 1:00 p.m. and between 5:00 p.m. - 8:00 p.m. for the Saturday. These 450 periods correspond to traffic peaks. The higher emission measured in the morning can be 451 explained by vehicle cold start, which emits large amounts of pollutants such as BC, PN, 452 BTEX, and carbonyl compounds. PN and BC emission factors show a good correlation, except the Tuesday afternoon between 2:00 p.m. - 8:00 p.m. The emission factor values for BC decreased while those for PN increased sharply. This could imply that the particle number emissions, especially the PN size between [0-50] nm, measured during this afternoon were not due to road traffic.

The impacts of the fleet composition on the pollutant emissions were studied by ANOVA analyses. These analyses show the positive impact of the higher percentage of gasoline PCs between Euro 4 and Euro 6 and Euro 4 diesel PCs on the BC emissions and the higher percentage of diesel and gasoline PCs between pre-Euro and Euro 3 on toluene, ethylbenzene, $m+p-x y l e n e$ and o-xylene emissions. The higher percentage of Euro 4 diesel PCs induces higher emission of ethylbenzene, $m+p-x y l e n e$ and o-xylene. And the number of HDVs present in the weekdays does not induce a significant impact on measured pollutant emissions since $80 \%$ of HDVs in the fleet is recent HDVs ( $\geq$ Euro 4 ).

The emission factors per vehicle were studied with boxplots and compared to other emission factors calculated in previous in-situ studies and with bench measurement. PN and $\mathrm{BC}$ emission factors assume a symmetric distribution contrary to the BTEX, alkanes and carbonyl compounds emission factors. For $\mathrm{PN}$ and $\mathrm{BC}$, the highest emission factors 
469 correspond to the same fleet composition with high percentage of diesel PCs. The highest

470 emission factors for hexanal, benzene, toluene, ethylbenzene and nonane correspond to a

471 fleet composition with high percentage of diesel PCs (85\%) and old PCs (65\%), and for $m+p$

472 and o Xylene, they correspond to high percentage of old PCs (61\%). These results have also

473 been observed by the ANOVA analyses for toluene, ethylbenzene, $m+p-x y l e n e$ and o-xylene.

474 The PN and BC emission factors estimated by other in-situ studies are in the same range as

475 the emission factors estimated in this work. For the chassis bench comparison, the PN and

$476 \mathrm{BC}$ emission factors estimated in this work are in the same range as those measured for

477 diesels PCs without particle filter, gasoline PCs with direct injection system and old HDVs. For

478 BTEX, bench emission factors are in the same range as in-situ emission factors estimated in

479 this work. 
480 Acknowledgements

481 This work was supported by the CEGEP (1666C0001) project, which is funded by the French

482 Environment and Energy Management Agency (ADEME). 


\section{Appendices}

\section{Table A.1}

498 Analytical methods for BTEX, carbonyl compounds, and PAH samples in the gas and particulate phases with quantification 499 limit and uncertainty

\begin{tabular}{|c|c|c|c|c|c|}
\hline Compound family & $\begin{array}{c}\text { Cartridge } \\
\text { type }\end{array}$ & $\begin{array}{l}\text { Analytical } \\
\text { technique }\end{array}$ & $\begin{array}{c}\text { Standardized } \\
\text { method }\end{array}$ & $\begin{array}{c}\text { Quantification } \\
\text { limit }\end{array}$ & $\begin{array}{l}\text { Analytical } \\
\text { uncertainty }\end{array}$ \\
\hline BTEX & & & & & \\
\hline Benzene & \multirow{5}{*}{ Tenax } & \multirow{5}{*}{ ATD-GC/MS* } & \multirow{5}{*}{ ISO $16000-6$} & $10 \mathrm{ng} / \mathrm{cartridge}$ & \multirow{5}{*}{$20 \%$} \\
\hline Toluene & & & & \multirow{4}{*}{$1 \mathrm{ng} /$ cartridge } & \\
\hline Ethylbenzene & & & & & \\
\hline m-p,Xylene & & & & & \\
\hline o-Xylene & & & & & \\
\hline Alkanes & & & & & \\
\hline Nonane & \multirow{5}{*}{ Tenax } & \multirow{5}{*}{ ATD-GC/MS* } & \multirow{5}{*}{ ISO 16000-6 } & \multirow{5}{*}{$1 \mathrm{ng} /$ cartridge } & \multirow{5}{*}{$20 \%$} \\
\hline Decane & & & & & \\
\hline Undecane & & & & & \\
\hline Cyclopropane, Ethyl & & & & & \\
\hline Cyclohexane, Ethyl & & & & & \\
\hline Carbonyl & & & & & \\
\hline Formaldehyde & \multirow{8}{*}{ DNPH } & \multirow{8}{*}{ HPLC/UV\# } & \multirow{8}{*}{ ISO $16000-3$} & \multirow{8}{*}{$30 \mathrm{ng} /$ cartridge } & \multirow{8}{*}{$20 \%$} \\
\hline Acetaldehyde & & & & & \\
\hline Acetone & & & & & \\
\hline Acrolein & & & & & \\
\hline Propionaldehyde & & & & & \\
\hline Crotonaldehyde & & & & & \\
\hline Methacrolein & & & & & \\
\hline Butanal & & & & & \\
\hline
\end{tabular}




\begin{tabular}{l|l|l|l|l|l}
\hline Benzaldehyde & & & & & \\
\hline Pentanal & & & & & \\
\hline Hexanal & & & & & \\
\hline *ATD-GC-MS: Automated Thermal Desorption - Gas Chromatograph - Mass Spectrometer
\end{tabular}

\section{1 \# HPCL/UV: High Performance Liquid Chromatography/Ultra Violet Detector}

502

505 Vehicle emission factors per hour for PN, BC, carbonyl compounds, BTEX and alkanes.

\section{Table A.2}

\begin{tabular}{|c|c|c|c|c|}
\hline Pollutants & & Emission factors (Min-Max) & Mean & $\begin{array}{l}\text { Standard } \\
\text { deviation }\end{array}$ \\
\hline PN & Weekdays & $1.2 \times 10^{13}-8.7 \times 10^{14}$ & $2 \times 10^{14}$ & $1.9 \times 10^{14}$ \\
\hline (\#/veh/km) & Weekend & $6.1 \times 10^{13}-5.3 \times 10^{14}$ & $1.7 \times 10^{14}$ & $1 \times 10^{14}$ \\
\hline BC & Weekdays & $1.7 \times 10^{6}-2.2 \times 10^{8}$ & $2.4 \times 10^{7}$ & $2.8 \times 10^{7}$ \\
\hline (ng/veh/km) & Weekend & $9 \times 10^{6}-9.3 \times 10^{7}$ & $4.7 \times 10^{7}$ & $2.1 \times 10^{7}$ \\
\hline Formaldehyde & Weekdays & $1.6 \times 10^{-1}-18$ & 3 & 3.9 \\
\hline (mg/veh/km) & Weekend & $6 \times 10^{-2}-13$ & 3.2 & 3.1 \\
\hline Hexanal & Weekdays & $1.4 \times 10^{-2}-2.8$ & $7.1 \times 10^{-1}$ & $8.8 \times 10^{-1}$ \\
\hline (mg/veh/km) & Weekend & $2.1 \times 10^{-1}-7.8$ & 1.8 & 1.8 \\
\hline Benzene & Weekdays & $9.1 \times 10^{-2}-7.4$ & 1.2 & 1.5 \\
\hline (mg/veh/km) & Weekend & $2.3 \times 10^{-1}-13.4$ & 2.4 & 3.5 \\
\hline Toluene & Weekdays & $3.4 \times 10^{-2}-11$ & 3 & 2.6 \\
\hline (mg/veh/km) & Weekend & $3.3-20.5$ & 9.6 & 4.7 \\
\hline Ethylbenzene & Weekdays & $1.3 \times 10^{-2}-2.6$ & $8.5 \times 10^{-1}$ & $7 \times 10^{-1}$ \\
\hline (mg/veh/km) & Weekend & $7 \times 10^{-1}-5$ & 2.6 & 1.2 \\
\hline
\end{tabular}




\begin{tabular}{ccccc}
\hline $\mathrm{m}+\mathrm{p}$ Xylene & Weekdays & $1.8 \times 10^{-1}-6.8$ & 1.6 & 1.5 \\
$(\mathrm{mg} / \mathrm{veh} / \mathrm{km})$ & Weekend & $1.4-10.4$ & 6.4 & 2.8 \\
\hline o Xylene & Weekdays & $7 \times 10^{-2}-2.9$ & $7.1 \times 10^{-1}$ & $6.4 \times 10^{-1}$ \\
$(\mathrm{mg} / \mathrm{veh} / \mathrm{km})$ & Weekend & $6.1 \times 10^{-1}-5.9$ & 3.2 & 1.6 \\
\hline Nonane & Weekdays & $3.5 \times 10^{-2}-3.3$ & $8 \times 10^{-1}$ & $7.5 \times 10^{-1}$ \\
(mg/veh/km) & Weekend & $3.3 \times 10^{-1}-4.9$ & 2 & 1.1 \\
\hline Decane & Weekdays & $1.5 \times 10^{-1}-15.2$ & 1.5 & 3.1 \\
$(\mathrm{mg} / \mathrm{veh} / \mathrm{km})$ & Weekend & $4.1 \times 10^{-2}-4.5$ & 1.7 & 1.3 \\
\hline Undecane & Weekdays & $5.5 \times 10^{-2}-4.8$ & $5.3 \times 10^{-1}$ & $8 . .9 \times 10^{-1}$ \\
(mg/veh/km) & Weekend & $3.5 \times 10^{-2}-2.1$ & 1.1 & $7 \times 10^{-1}$ \\
\hline
\end{tabular}

Table A.3

509 Example of COPERT input data for calculating $\mathrm{NO}_{\mathrm{x}}$ emission factors

\begin{tabular}{ccccccc}
\hline Category & Fuel & Segment & $\begin{array}{c}\text { Euro } \\
\text { Standard }\end{array}$ & $\begin{array}{c}\text { Stock } \\
{[\mathbf{n}]}\end{array}$ & $\begin{array}{c}\text { Mean } \\
\text { Activity } \\
{[\mathbf{k m} / \text { year }]}\end{array}$ & $\begin{array}{c}\text { Urban } \\
\text { Speed } \\
{[\mathbf{k m} / \mathbf{h}]}\end{array}$ \\
\hline Passenger Cars & Gasoline & Small & PRE ECE & 0 & 0 & 25 \\
Passenger Cars & Gasoline & Small & Euro 1 & 1 & 4077 & 25 \\
Passenger Cars & Gasoline & Small & Euro 2 & 2 & 5055 & 25 \\
Passenger Cars & Gasoline & Small & Euro 3 & 1 & 6820 & 25 \\
Passenger Cars & Gasoline & Small & Euro 4 & 2 & 8508 & 25 \\
Passenger Cars & Gasoline & Small & Euro 5 & 1 & 11007 & 25 \\
Passenger Cars & Gasoline & Small & Euro 6 & 5 & 13309 & 25 \\
Passenger Cars & Gasoline & Medium & PRE ECE & 0 & 0 & 25 \\
Passenger Cars & Gasoline & Medium & Euro 1 & 2 & 5398 & 25 \\
Passenger Cars & Gasoline & Medium & Euro 2 & 4 & 6672 & 25 \\
Passenger Cars & Gasoline & Medium & Euro 3 & 5 & 8995 & 25 \\
Passenger Cars & Gasoline & Medium & Euro 4 & 0 & 11319 & 25
\end{tabular}




\begin{tabular}{|c|c|c|c|c|c|c|}
\hline Passenger Cars & Gasoline & Medium & Euro 5 & 2 & 14555 & 25 \\
\hline Passenger Cars & Gasoline & Medium & Euro 6 & 3 & 17592 & 25 \\
\hline Passenger Cars & Gasoline & Large-SUV-Executive & PRE ECE & 0 & 0 & 25 \\
\hline Passenger Cars & Gasoline & Large-SUV-Executive & Euro 1 & 0 & 5610 & 25 \\
\hline Passenger Cars & Gasoline & Large-SUV-Executive & Euro 2 & 0 & 7069 & 25 \\
\hline Passenger Cars & Gasoline & Large-SUV-Executive & Euro 3 & 0 & 9523 & 25 \\
\hline Passenger Cars & Gasoline & Large-SUV-Executive & Euro 4 & 1 & 12000 & 25 \\
\hline Passenger Cars & Gasoline & Large-SUV-Executive & Euro 5 & 0 & 15454 & 25 \\
\hline Passenger Cars & Gasoline & Large-SUV-Executive & Euro 6 & 3 & 18619 & 25 \\
\hline Passenger Cars & Diesel & Mini & Euro 4 & 10 & 15608 & 25 \\
\hline Passenger Cars & Diesel & Mini & Euro 5 & 5 & 17572 & 25 \\
\hline Passenger Cars & Diesel & Mini & Euro 6 & 5 & 19 & 25 \\
\hline Passenger Cars & Diesel & Small & Euro 1 & 1 & 10957 & 25 \\
\hline Passenger Cars & Diesel & Small & Euro 2 & 3 & 12152 & 25 \\
\hline Passenger Cars & Diesel & Small & Euro 3 & 7 & 13560 & 25 \\
\hline Passenger Cars & Diesel & Small & Euro 4 & 16 & 15236 & 25 \\
\hline Passenger Cars & Diesel & Small & Euro 5 & 12 & 17146 & 25 \\
\hline Passenger Cars & Diesel & Small & Euro 6 & 17 & 18122 & 25 \\
\hline Passenger Cars & Diesel & Large-SUV-Executive & Euro 1 & 0 & 11376 & 25 \\
\hline Passenger Cars & Diesel & Large-SUV-Executive & Euro 2 & 1 & 12489 & 25 \\
\hline Passenger Cars & Diesel & Large-SUV-Executive & Euro 3 & 2 & 14286 & 25 \\
\hline Passenger Cars & Diesel & Large-SUV-Executive & Euro 4 & 2 & 15807 & 25 \\
\hline Passenger Cars & Diesel & Large-SUV-Executive & Euro 5 & 2 & 17770 & 25 \\
\hline Passenger Cars & Diesel & Large-SUV-Executive & Euro 6 & 2 & 18788 & 25 \\
\hline $\begin{array}{l}\text { Light Commercial } \\
\text { Vehicles }\end{array}$ & Diesel & N1-II & Conventional & 0 & 2313 & 25 \\
\hline $\begin{array}{l}\text { Light Commercial } \\
\text { Vehicles }\end{array}$ & Diesel & N1-II & Euro 1 & 0 & 5012 & 25 \\
\hline $\begin{array}{l}\text { Light Commercial } \\
\text { Vehicles }\end{array}$ & Diesel & N1-II & Euro 2 & 0 & 7490 & 25 \\
\hline $\begin{array}{l}\text { Light Commercial } \\
\text { Vehicles }\end{array}$ & Diesel & N1-II & Euro 3 & 2 & 10979 & 25 \\
\hline $\begin{array}{l}\text { Light Commercial } \\
\text { Vehicles }\end{array}$ & Diesel & N1-II & Euro 4 & 9 & 15840 & 25 \\
\hline $\begin{array}{l}\text { Light Commercial } \\
\text { Vehicles }\end{array}$ & Diesel & N1-II & Euro 5 & 13 & 21249 & 25 \\
\hline $\begin{array}{c}\text { Light Commercial } \\
\text { Vehicles }\end{array}$ & Diesel & N1-II & Euro 6 & 23 & 25636 & 25 \\
\hline Heavy Duty Trucks & Diesel & Rigid $<=7,5 \mathrm{t}$ & Euro I & 0 & 846 & 25 \\
\hline Heavy Duty Trucks & Diesel & Rigid $<=7,5 \mathrm{t}$ & Euro II & 0 & 4475 & 25 \\
\hline
\end{tabular}




\begin{tabular}{|c|c|c|c|c|c|c|}
\hline Heavy Duty Trucks & Diesel & Rigid $<=7,5 \mathrm{t}$ & Euro III & 0 & 11207 & 25 \\
\hline Heavy Duty Trucks & Diesel & Rigid $<=7,5 \mathrm{t}$ & Euro IV & 0 & 19789 & 25 \\
\hline Heavy Duty Trucks & Diesel & Rigid $<=7,5 \mathrm{t}$ & Euro V & 0 & 32935 & 25 \\
\hline Heavy Duty Trucks & Diesel & Rigid $<=7,5 \mathrm{t}$ & Euro VI & 0 & 50409 & 25 \\
\hline Heavy Duty Trucks & Diesel & Rigid 7,5 - $12 \mathrm{t}$ & Euro I & 0 & 903 & 25 \\
\hline Heavy Duty Trucks & Diesel & Rigid $7,5-12 t$ & Euro II & 0 & 4404 & 25 \\
\hline Heavy Duty Trucks & Diesel & Rigid 7,5 - $12 \mathrm{t}$ & Euro III & 0 & 11191 & 25 \\
\hline Heavy Duty Trucks & Diesel & Rigid 7,5 - $12 \mathrm{t}$ & Euro IV & 1 & 19733 & 25 \\
\hline Heavy Duty Trucks & Diesel & Rigid 7,5 - $12 \mathrm{t}$ & Euro V & 1 & 33797 & 25 \\
\hline Heavy Duty Trucks & Diesel & Rigid 7,5 - $12 \mathrm{t}$ & Euro VI & 0 & 53438 & 25 \\
\hline Heavy Duty Trucks & Diesel & Rigid $14-20 t$ & Euro I & 0 & 952 & 25 \\
\hline Heavy Duty Trucks & Diesel & Rigid $14-20 t$ & Euro II & 0 & 4598 & 25 \\
\hline Heavy Duty Trucks & Diesel & Rigid $14-20 t$ & Euro III & 0 & 11195 & 25 \\
\hline Heavy Duty Trucks & Diesel & Rigid 14 - 20 t & Euro IV & 0 & 19669 & 25 \\
\hline Heavy Duty Trucks & Diesel & Rigid 14 - $20 \mathrm{t}$ & Euro V & 0 & 33306 & 25 \\
\hline Heavy Duty Trucks & Diesel & Rigid $14-20 t$ & Euro VI & 1 & 50609 & 25 \\
\hline Heavy Duty Trucks & Diesel & Rigid $20-26 t$ & Euro I & 0 & 983 & 25 \\
\hline Heavy Duty Trucks & Diesel & Rigid $20-26 t$ & Euro II & 0 & 4800 & 25 \\
\hline Heavy Duty Trucks & Diesel & Rigid $20-26 t$ & Euro III & 0 & 11470 & 25 \\
\hline Heavy Duty Trucks & Diesel & Rigid $20-26 t$ & Euro IV & 0 & 19795 & 25 \\
\hline Heavy Duty Trucks & Diesel & Rigid $20-26 t$ & Euro V & 0 & 33762 & 25 \\
\hline Heavy Duty Trucks & Diesel & Rigid $20-26 \mathrm{t}$ & Euro VI & 0 & 50832 & 25 \\
\hline Heavy Duty Trucks & Diesel & Rigid 26 - $28 \mathrm{t}$ & Conventional & 0 & 0 & 25 \\
\hline Heavy Duty Trucks & Diesel & Rigid 26 - $28 \mathrm{t}$ & Euro I & 0 & 995 & 25 \\
\hline Heavy Duty Trucks & Diesel & Rigid 26 - $28 \mathrm{t}$ & Euro II & 0 & 4999 & 25 \\
\hline Heavy Duty Trucks & Diesel & Rigid 26 - 28 t & Euro III & 0 & 11940 & 25 \\
\hline Heavy Duty Trucks & Diesel & Rigid 26 - $28 \mathrm{t}$ & Euro IV & 0 & 19884 & 25 \\
\hline Heavy Duty Trucks & Diesel & Rigid 26 - 28 t & Euro V & 2 & 34084 & 25 \\
\hline Heavy Duty Trucks & Diesel & Rigid $26-28 t$ & Euro VI & 0 & 50947 & 25 \\
\hline Buses & Diesel & $\begin{array}{c}\text { Urban Buses Midi } \\
<=15 \mathrm{t}\end{array}$ & Euro IV & 0 & 27800 & 25 \\
\hline Buses & Diesel & $\begin{array}{c}\text { Urban Buses Midi } \\
<=15 \mathrm{t}\end{array}$ & Euro V & 0 & 38074 & 25 \\
\hline Buses & Diesel & $\begin{array}{c}\text { Urban Buses Midi } \\
<=15 \mathrm{t}\end{array}$ & Euro VI & 0 & 45582 & 25 \\
\hline Buses & Diesel & $\begin{array}{c}\text { Urban Buses } \\
\text { Articulated }>18 \mathrm{t}\end{array}$ & Conventional & 0 & 2000 & 25 \\
\hline Buses & Diesel & $\begin{array}{c}\text { Urban Buses } \\
\text { Articulated }>18 \mathrm{t}\end{array}$ & Euro I & 0 & 5823 & 25 \\
\hline
\end{tabular}



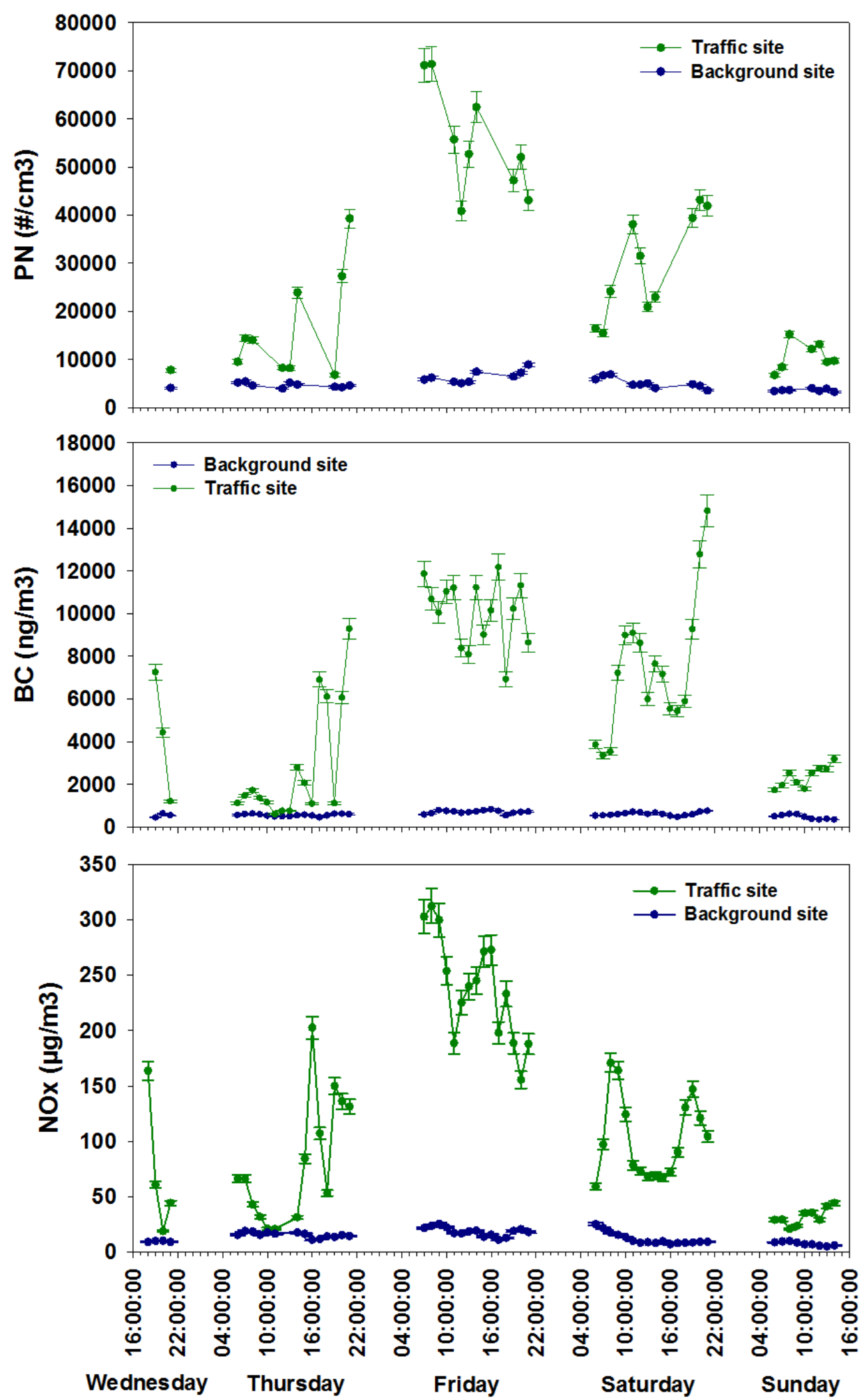

512 Fig. A.1. Time profiles of $\mathrm{PN}, \mathrm{BC}$ and $\mathrm{NO}_{\mathrm{x}}$ concentrations on the traffic site and the background site From Wednesday to 513 Sunday. 

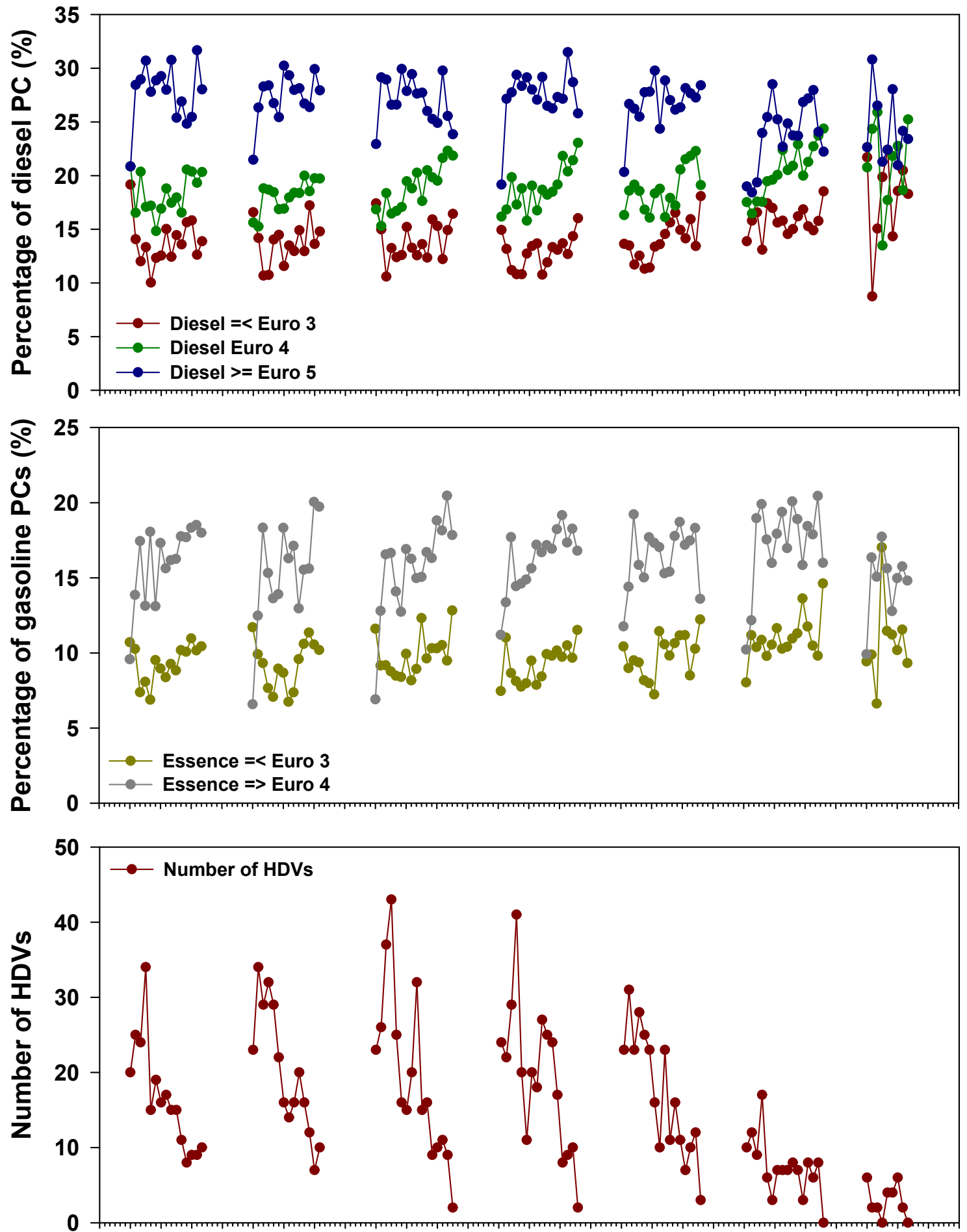

ㅇㅇㅇㅇㅇㅇㅇㅇㅇㅇㅇㅇㅇㅇㅇㅇㅇㅇㅇㅇㅇㅇㅇㅇㅇㅇㅇㅇㅇㅇㅇㅇㅇㅇㅇㅇㅇ 융

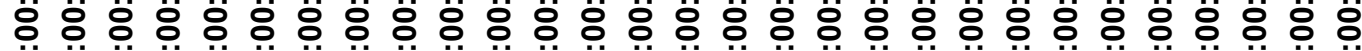
ठ் $\ddot{\theta}$ i் $\begin{array}{ccccccc}\text { Monday, } & \text { Tuesday, } & \text { Wednesday, } & \text { Thursday, } & \text { Friday, } & \text { Saturday, Sunday, } \\ \text { April 24th } & \text { April 25th } & \text { April 26th } & \text { April 27th } & \text { April 28th } & \text { April 29th April 30th }\end{array}$

515 Fig. A.2. Time profiles of the percentages of the diesel PCs, the percentages of gasoline PCs and the numbers of HDVs on 516 the measurement week. 


\section{References}

518lves, C.A., Lopes, D.J., Calvo, A.I., Evtyugina, M., Rocha, S., Nunes, T., 2015. Emissions from light-

519 duty diesel and gasoline in-use vehicles measured on chassis dynamometer test cycles.

520 Aerosol Air Qual Res 15, 99-116.

52Andre, M., Roche, A.L., Bourcier, L., 2014. Statistiques de parcs et trafic pour le calcul des

522 émissions de polluants des transports routiers en France. Final report (in French), IFSTTAR

523 LTE, available at. http://www.ademe.fr/statistiques-parcstrafic-calcul-emissions-polluants-

524 transports-routiers-france.

52Amato, F., Nava, S., Lucarelli, F., Querol, X., Alastuey, A., Baldasano, J.M., Pandolfi, M., 2010. A

526 comprehensive assessment of PM emissions from paved roads: Real-world Emission Factors

527 and intense street cleaning trials. Science of The Total Environment 408, 4309-4318.

52Bukowiecki, N., Lienemann, P., Hill, M., Furger, M., Richard, A., Amato, F., Prévôt, A.S.H.,

529 Baltensperger, U., Buchmann, B., Gehrig, R., 2010. PM10 emission factors for non-exhaust

530 particles generated by road traffic in an urban street canyon and along a freeway in

531 Switzerland. Atmospheric Environment 44, 2330-2340.

53lanagaratna, M.R., Jayne, J.T., Ghertner, D.A., Herndon, S., Shi, Q., Jimenez, J.L., Silva, P.J.,

533 Williams, P., Lanni, T., Drewnick, F., others, 2004. Chase studies of particulate emissions from 534 in-use New York City vehicles. Aerosol Science and Technology 38, 555-573.

536aplain, I., Cazier, F., Nouali, H., Mercier, A., Déchaux, J.-C., Nollet, V., Joumard, R., André, J.-M., 536 Vidon, R., 2006. Emissions of unregulated pollutants from European gasoline and diesel 537 passenger cars. Atmospheric Environment 40, 5954-5966.

53Banelli, R.M., Di Nocera, A., 2018. Customer perceptions of Japanese foods in Italy. Journal of 539 Ethnic Foods. 
540iechaskiel, B., Mamakos, A., Andersson, J., Dilara, P., Martini, G., Schindler, W., Bergmann, A.,

541 2012. Measurement of Automotive Nonvolatile Particle Number Emissions within the

542 European Legislative Framework: A Review. Aerosol Science and Technology 46, 719-749.

54Giechaskiel, B., 2018. Solid Particle Number Emission Factors of Euro VI Heavy-Duty Vehicles on

544 the Road and in the Laboratory. Int J Environ Res Public Health 15.

546ietl, J.K., Lawrence, R., Thorpe, A.J., Harrison, R.M., 2010. Identification of brake wear particles

546 and derivation of a quantitative tracer for brake dust at a major road. Atmospheric

547 Environment 44, 141-146.

54Bludda, N., Fruin, S., Delfino, R.J., Sioutas, C., 2013. Efficient determination of vehicle emission

549 factors by fuel use category using on-road measurements: downward trends on Los Angeles

550 freight corridor I-710. Atmospheric chemistry and physics 13, 347-357.

55tmhof, D., Weingartner, E., Ordóñez, C., Gehrig, R., Hill, M., Buchmann, B., Baltensperger, U., 552 2005. Real-world emission factors of fine and ultrafine aerosol particles for different traffic 553 situations in Switzerland. Environmental science \& technology 39, 8341-8350.

55łkžek, I., Drinovec, L., Ferrero, L., Carriero, M., Močnik, G., 2015. Determination of car on-road 555 black carbon and particle number emission factors and comparison between mobile and 556 stationary measurements. Atmospheric Measurement Techniques 8, 43-55.

55Johansson, C., Norman, M., Burman, L., 2009. Road traffic emission factors for heavy metals.

558 Atmospheric Environment, Urban Air Quality 43, 4681-4688.

5500nes, A.M., Harrison, R.M., 2006. Estimation of the emission factors of particle number and mass 560 fractions from traffic at a site where mean vehicle speeds vary over short distances.

561 Atmospheric Environment 40, 7125-7137.

56Dumard, R., André, M., Vidon, R., Tassel, P., Pruvost, C., 2000. Influence of driving cycles on unit 563 emissions from passenger cars. Atmospheric environment 34, 4621-4628. 
56Kam, W., Liacos, J.W., Schauer, J.J., Delfino, R.J., Sioutas, C., 2012. On-road emission factors of PM

565 pollutants for light-duty vehicles (LDVs) based on urban street driving conditions.

566 Atmospheric Environment 61, 378-386.

56Rarjalainen, P., Pirjola, L., Heikkilä, J., Lähde, T., Tzamkiozis, T., Ntziachristos, L., Keskinen, J.,

568 Rönkkö, T., 2014. Exhaust particles of modern gasoline vehicles: A laboratory and an on-road 569 study. Atmospheric Environment 97, 262-270.

57ketzel, M., Wåhlin, P., Berkowicz, R., Palmgren, F., 2003. Particle and trace gas emission factors 571 under urban driving conditions in Copenhagen based on street and roof-level observations.

572 Atmospheric Environment 37, 2735-2749.

57ßBrecl, P., Johansson, C., Targino, A.C., Ström, J., Burman, L., 2017. Trends in black carbon and size-

574 resolved particle number concentrations and vehicle emission factors under real-world 575 conditions. Atmospheric Environment 165, 155-168.

57krecl, P., Targino, A.C., Landi, T.P., Ketzel, M., 2018. Determination of black carbon, PM 2.5, 577 particle number and NOx emission factors from roadside measurements and their 578 implications for emission inventory development. Atmospheric Environment.

57lewtas, J., 2007. Air pollution combustion emissions: Characterization of causative agents and 580 mechanisms associated with cancer, reproductive, and cardiovascular effects. Mutation

581 Research/Reviews in Mutation Research, The Sources and Potential Hazards of Mutagens in 582 Complex Environmental Matrices - Part II 636, 95-133.

58Biang, B., Ge, Y., Tan, J., Han, X., Gao, L., Hao, L., Ye, W., Dai, P., 2013. Comparison of PM 584 emissions from a gasoline direct injected (GDI) vehicle and a port fuel injected (PFI) vehicle 585 measured by electrical low pressure impactor (ELPI) with two fuels: Gasoline and M15 586 methanol gasoline. Journal of Aerosol Science 57, 22-31. 
58Ziu, Y., Martinet, S., Louis, C., Pasquier, A., Tassel, P., Perret, P., 2017. Emission Characterization of 588 In-Use Diesel and Gasoline Euro 4 to Euro 6 Passenger Cars Tested on Chassis Dynamometer 589 Bench and Emission Model Assessment. Aerosol and Air Quality Research 17, 2289-2299. 59Dohmeyer, A., Lambrecht, U., Peranic, Z., Boesinger, R. 2002. Validation of vehicle road PM10 591 emission models by the Karlsruhe PM10 validation data set and the results of the regular 592 German state monitoring stations. In: Proceedings of the Eighth International Conference on 593 Harmonisation within atmospheric Dispersion Modelling for Regulatory Purposes. Sofia, 594 Bulgaria.

595ouis, C., Liu, Y., Tassel, P., Perret, P., Chaumond, A., André, M., 2016. PAH, BTEX, carbonyl 596 compound, black-carbon, NO2 and ultrafine particle dynamometer bench emissions for Euro 5974 and Euro 5 diesel and gasoline passenger cars. Atmospheric Environment 141, 80-95.

598/artinet, S., Liu, Y., Louis, C., Tassel, P., Perret, P., Chaumond, A., André, M., 2017. Euro 6 599 Unregulated Pollutant Characterization and Statistical Analysis of After-Treatment Device 600 and Driving-Condition Impact on Recent Passenger-Car Emissions. Environ. Sci. Technol. 51, $601 \quad 5847-5855$.

60冈ing, Z., Wubulihairen, M., Yang, F., 2012. PM, NOx and butane emissions from on-road vehicle 603 fleets in Hong Kong and their implications on emission control policy. Atmospheric 604 Environment 61, 265-274.

60\$Itziachristos, L., Papadimitriou, G., Ligterink, N., Hausberger, S., 2016. Implications of diesel 606 emissions control failures to emission factors and road transport NO x evolution.

607 Atmospheric Environment 141, 542-551.

608'Driscoll, R., ApSimon, H.M., Oxley, T., Molden, N., Stettler, M.E., Thiyagarajah, A., 2016. A 609 Portable Emissions Measurement System (PEMS) study of NOx and primary NO2 emissions 
610 from Euro 6 diesel passenger cars and comparison with COPERT emission factors.

611 Atmospheric Environment 145, 81-91.

61Zant, P., Harrison, R.M., 2013. Estimation of the contribution of road traffic emissions to 613 particulate matter concentrations from field measurements: a review. Atmospheric 614 Environment 77, 78-97.

61Behn, L.P., 2013. Caractérisation et impacts des émissions de polluants du transport routier :

616 Apports méthodologiques et cas d'études en Rhône Alpes. (phdthesis). Université de 617 Grenoble.

61Bexeis, M., 2013. Update of Emission Factors for EURO 5 and EURO 6 vehicles for the HBEFA 619 Version 3.2. Report No. I-31/2013/ Rex EM-I 2011/20/679 from 06.12.2013.

62Rose, D., Wehner, B., Ketzel, M., Engler, C., Voigtländer, J., Tuch, T., Wiedensohler, A., 2005.

621 Atmospheric number size distributions of soot particles and estimation of emission factors.

622 Atmospheric Chemistry and Physics Discussions 5, 10125-10154.

62Sluder, C.S., West, B.H., 2000. Catalyzed diesel particulate filter performance in a light-duty 624 vehicle. SAE Technical Paper.

62Sydbom, A., Blomberg, A., Parnia, S., Stenfors, N., Sandström, T., Dahlén, S.-E., 2001. Health 626 effects of diesel exhaust emissions. European Respiratory Journal 17, 733-746.

62Wang, X., Westerdahl, D., Chen, L.C., Wu, Y., Hao, J., Pan, X., Guo, X., Zhang, K.M., 2009.

628 Evaluating the air quality impacts of the 2008 Beijing Olympic Games: on-road emission

629 factors and black carbon profiles. Atmospheric Environment 43, 4535-4543.

63Westerdahl, D., Wang, X., Pan, X., Zhang, K.M., 2009. Characterization of on-road vehicle emission

631 factors and microenvironmental air quality in Beijing, China. Atmospheric Environment 43, $632 \quad 697-705$. 
63BVesterholm, R., Christensen, A., Rosén, \AAke, 1996. Regulated and unregulated exhaust

634 emissions from two three-way catalyst equipped gasoline fuelled vehicles. Atmospheric

635 Environment 30, 3529-3536.

636Vildt, A. R., \& Ahtola, O. T. (1978). Analysis of covariance. Newbury Park, CA: Sage Publications. 637 View

638li-Tuomi, T., Aarnio, P., Pirjola, L., Mäkelä, T., Hillamo, R., Jantunen, M., 2005. Emissions of fine 639 particles, NOx, and CO from on-road vehicles in Finland. Atmospheric Environment 39, $640 \quad 6696-6706$.

64Yang, L., Franco, V., Mock, P., Kolke, R., Zhang, S., Wu, Y. and German, J., 2015. Experimental 642 Assessment of NOx Emissions from 73 Euro 6 Diesel Passenger Cars. Environ. Sci. Technol. 643 49: 14409-14415. 